\title{
LA FUENTE COLECTIVA. (RETAZOS DEL FRENTE). (TROZOS DE GUERRA Y POSTGUERRA)
}

\author{
The collective source. (Snippets from the front.) \\ (Scraps from the war and the post-war)
}

\author{
Jean-Louis Guereña ${ }^{\&}$ \\ Fecha de recepción: 03/10/2018 • Fecha de aceptación: 11/10/2018
}

Resumen. En este texto documental se reproduce parte del diario que, con el título de La fuente colectiva, escribió Jacinto Luis Guereña, un joven oficial, recién salido de la Escuela Popular de Guerra, desde el 22 de mayo de 1938 en Igualada, a la espera de la ofensiva republicana en el Ebro, al 23 de septiembre de 1940, ya en Francia, tras el paso por diversos campos de concentración para los refugiados españoles. Los fragmentos transcritos corresponden al periodo de la batalla del Ebro ( 25 de julio de 1938 al 16 de noviembre de 1938), la retirada, el paso de la frontera francesa (el 9 de febrero de 1939), los campos de concentración y la vida en el exilio francés.

Palabras clave: Diarios; Guerra civil española; Exilio republicano: Jacinto Luis Guereña.

Abstract. In this documentary text we reproduce part of the diary titled The Collective Source, written by Juan Luis Guereña. The writings of the young official stretch from 22 May, 1938, when he was in Igualada anticipating the launch of the republican offensive of the Ebro, until 23 September, 1940, when he was in France, having been at several concentration camps for Spanish refugees. The fragments transcribed correspond to the Battle of the Ebro (25 July, 1938 until 16 November, 1938), the retreat, the crossing into France (9 February, 1939), the concentration camps and those involving life in exile in France.

Keywords: Diaries. Spanish Civil War. Republican exile. Jacinto Luis Guereña.

\footnotetext{
\& ICD, Université François-Rabelais, Tours. 3, Rue des Tanneurs. 37041 Tours Cedex. Francia jeanlouis.guerena@univ-tours.fr
}

Cómo citar este artículo: Guereña, Jean-Louis. «La fuente colectiva. (Retazos del frente). (Trozos de guerra y postguerra)». Historia y Memoria de la Educación 9 (2019): 711-779. 


\section{INTRODUCCIÓN}

El documento que presentamos y que lleva como título «La fuente colectiva» acompaña al artículo «Un joven maestro exiliado en Francia, Jacinto Luis Guereña (1939-1956)» incluido en la parte monográfica de este número de Historia y Memoria de la Educación. Se trata del diario de un joven oficial, recién salido de la Escuela Popular de Guerra, redactado desde el 22 de mayo de 1938 en Igualada, a la espera de la ofensiva republicana en el Ebro, al 23 de setiembre de 1940, ya en Francia, tras el paso por diversos campos de concentración para los refugiados españoles.

El diario, muy desigual en cuanto a las fechas de redacción, cubre, pues, el periodo de la batalla del Ebro (25 de julio de 1938 al 16 de noviembre de 1938), la retirada, el paso de la frontera francesa (el 9 de febrero de 1939), los campos y la vida en el exilio francés.

No presentaremos aquí al autor del diario, Jacinto Luis Guereña Seggiaro [1915-2007], pues su biografía viene recogida en parte, como se dijo, en el artículo mencionado, y sobre todo en la «Semblanza de un itinerario intelectual y humano (1915-2007)», publicada como introducción a su antología poética (1946-2001), Corazón de miedo y de sueños (Sevilla, Renacimiento, 2013), 9-95.

Recordemos solo que, nacido en Argentina, pasó su juventud y adolescencia en Marruecos. Ya en Madrid, con la República, ingresó en la Escuela Normal de magisterio primario n. ${ }^{\circ} 2$ de la capital acabando el periodo «teórico» de los estudios normalistas en junio de 1936. Pero, como se sabe, el curso de los acontecimientos históricos iba a modificar por completo el rumbo previsible de su vida profesional y social.

Tras la sublevación franquista de julio de 1936, y ya comprometido política y socialmente en las filas de la Federación Universitaria Escolar (FUE), Jacinto Luis Guereña no vaciló en ponerse al servicio de la República, primero como miliciano (en el marco de las «Milicias Vascas Antifascistas»), luego como soldado del nuevo Ejército popular de la República, «Miliciano de la cultura», y ya teniente, tras su paso por la Escuela Popular de Guerra en la especialidad de Ingenieros.

Materialmente, el documento, del cual reproducimos las primeras páginas, está escrito en una pequeña agenda de canutillo de 10 por 
15 centímetros y de pequeños cuadros. Se trata en total de 126 páginas escritas con pluma estilográfica (con tinta azul y negra). El título general, La fuente colectiva, viene explicado en la primera página por lo que parece no haber sido redactado a posteriori:

Ha surgido una integración de nuestras ideas y de nuestra sangre popular: la guerra. Al vivirla, sintiendo su duro aguijón, ha nacido como fuente colectiva. Fuente de todo. De formas de vivir y de emocionarse. De línea social y política. De maneras de interpretar. De poesía y de arte. De estilos de escribir. De conceptos.

A menudo, el joven oficial comprometido con la causa republicana deja paso al poeta y sus notas cobran una dimensión lírica, no informativa. Pero también la línea docente sigue presente. Significativamente, la última página del cuaderno (fechada el 23 de septiembre de 1940) se refiere a su nombramiento como profesor (de hecho, auxiliar de conversación): «Sí de nuevo. Continuar la línea de Madrid». 


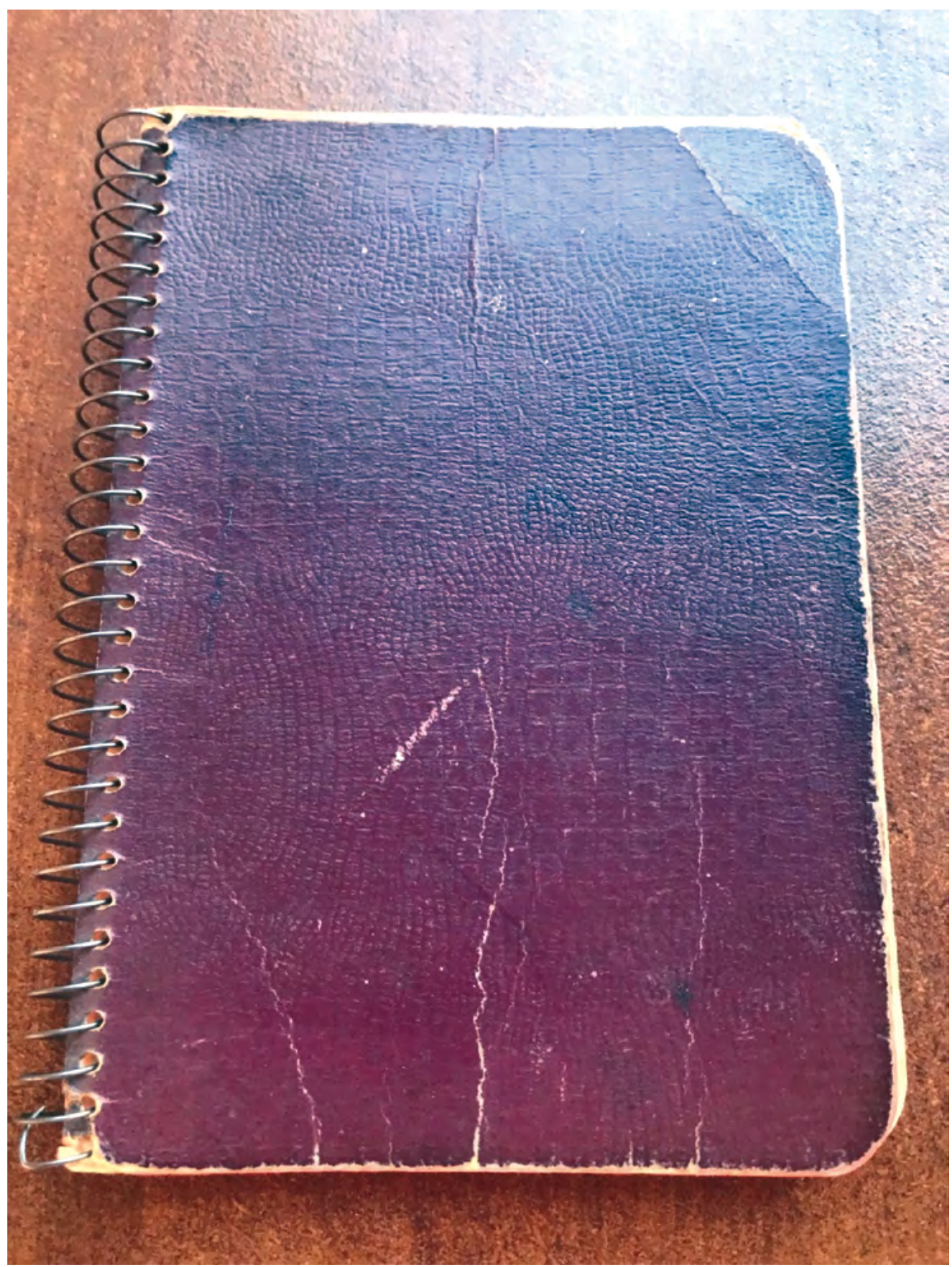

714 Historia y Memoria de la Educación, 9 (2019): 711-779 


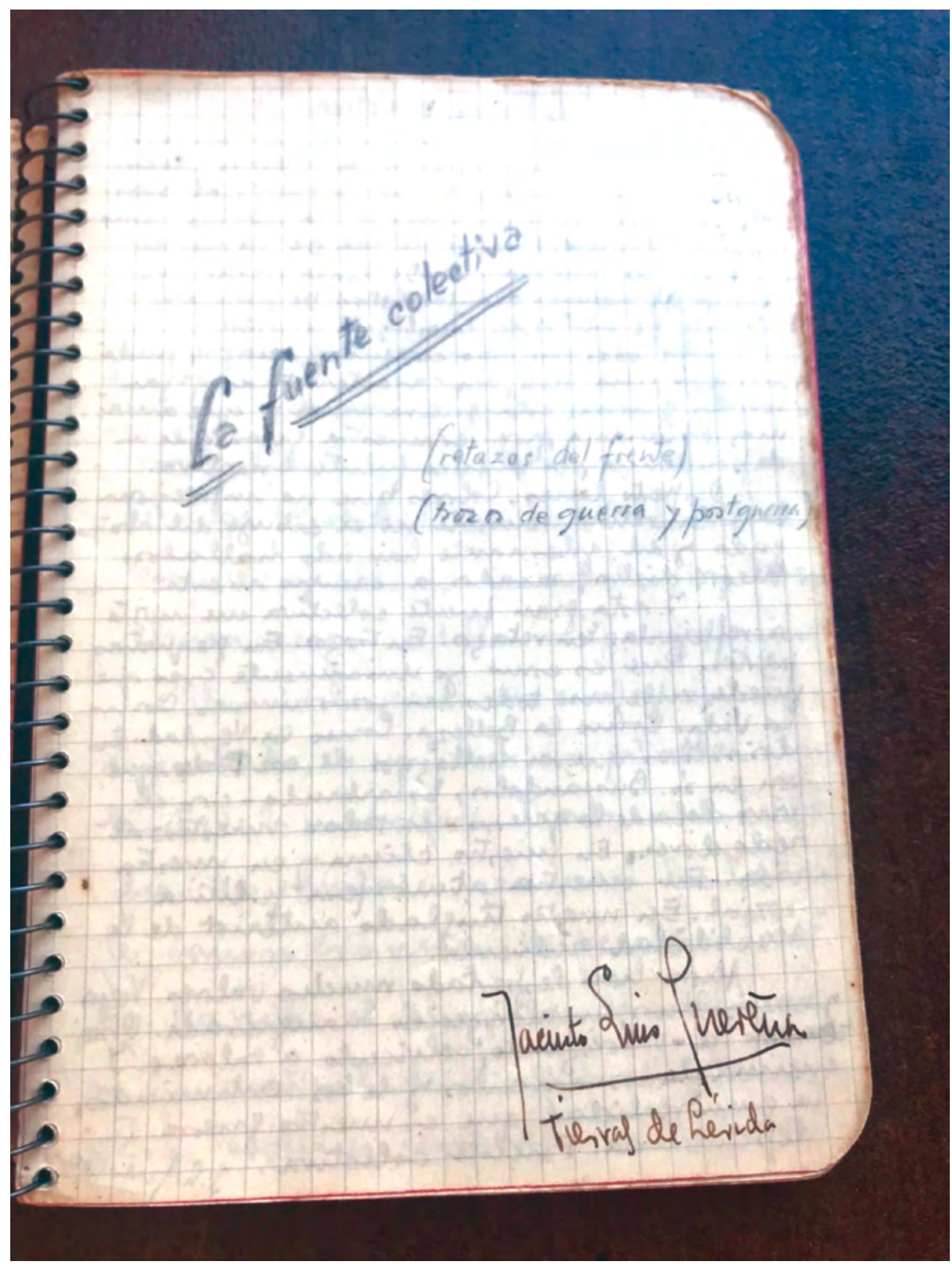









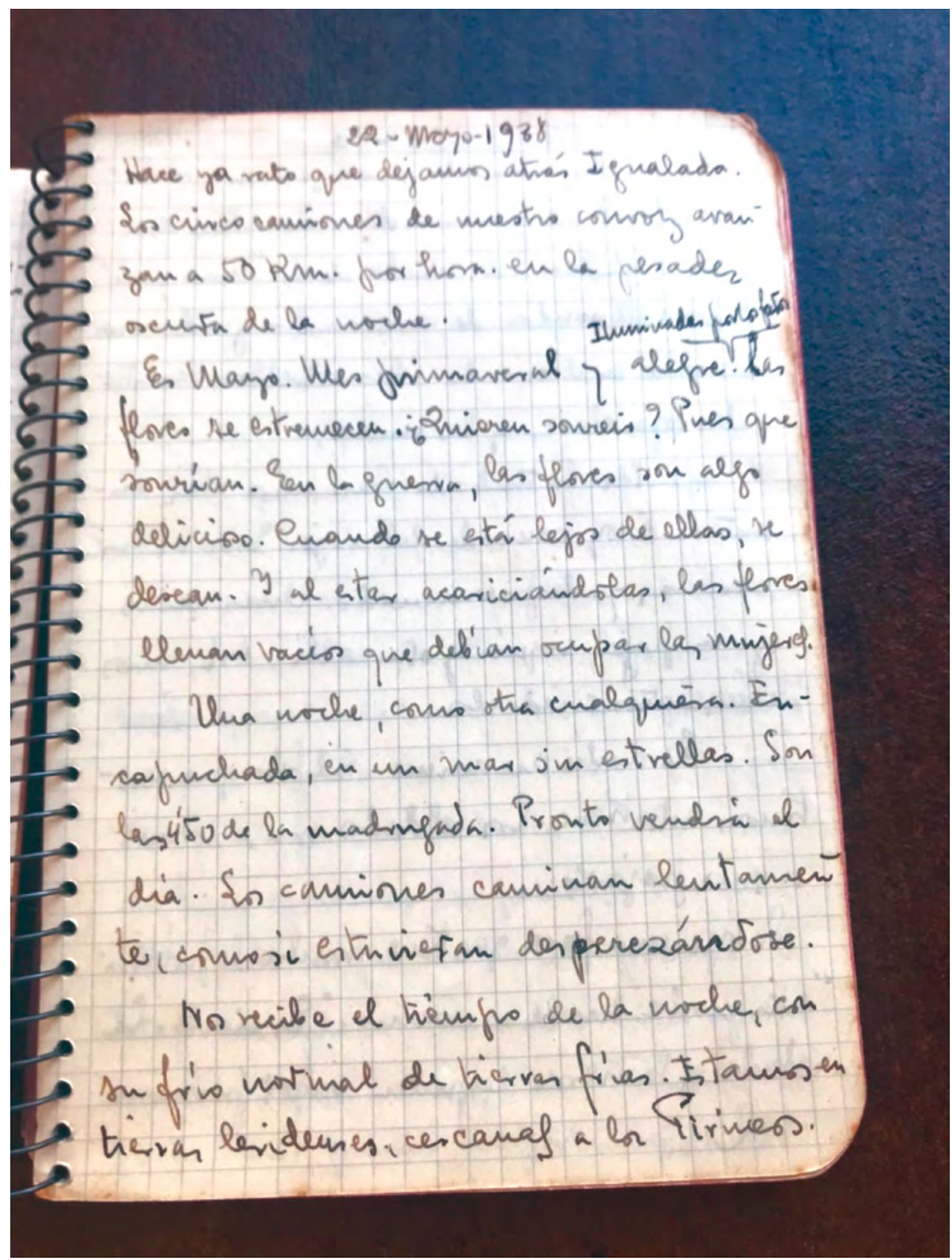




\section{LA FUENTE COLECTIVA \\ (RETAZOS DEL FRENTE) \\ (TROZOS DE GUERRA Y POST GUERRA)}

Jacinto Luis Guereña

Tierras de Lérida ${ }^{1}$

\section{LA FUENTE COLECTIVA}

Ha surgido una integración de nuestras ideas y de nuestra sangre popular: la guerra. Al vivirla, sintiendo su duro aguijón, ha nacido como fuente colectiva. Fuente de todo. De formas de vivir y de emocionarse. De línea social y política. De maneras de interpretar. De poesía y de arte. De estilos de escribir. De conceptos.

Sobre todas sus consecuencias, siempre predominará una. Una, con características gigantes. La guerra, esta guerra cruel y que amamos odiándola por ser nuestra guerra de independencia, es nuestra fuente colectiva.

Despertó luces. Colores que no impresionaban la retina sensible ni el dibujo del abogado y del gobernante han sido hallados. Mejor dicho, sacados a campo abierto.

Y esta gran fuente colectiva me invita a reflejarla. En retazos. En trozos. En pequeñas partes. Que es como yo únicamente creo que pueden reflejarse todas las cosas únicas. Como la vida. Como la belleza. Como la verdad. En dosis. Y es que son hallazgos de ese todo que son en sí. Buscándolos. Escarbando — con el vivo dolor de la guerra- en todos nuestros alrededores. En nuestro clima y en nuestra vida. En nuestra atmósfera política y social. En nuestro tinglado anterior de la sensibilidad ridícula.

Ahora han despertado muchos valores. Viejos y nuevos. Unos en valorización inaugurada. Otros, re-valorizando, volviendo a valorar. Y en-

\footnotetext{
${ }^{1}$ Transcripción de Marisa Guereña Mercier. Este documento inédito, encontrado entre sus papeles, acompaña la biografía de Jacinto Luis Guereña publicada en este mismo número de Historia y Memoria de la Educación.
} 
cima de los cálculos y de los sentimientos, la gran realidad que es nuestra guerra. Independencia. Fuente colectiva.

Firmado. J.L. Guereña

\section{2-mayo-1938}

Hace ya rato que dejamos atrás Igualada. Los cinco camiones de nuestro convoy avanzan a $50 \mathrm{~km}$. por hora en la pesadez oscura de la noche.

Es mayo. Mes primaveral y alegre. Iluminadas por los faros, las flores se estremecen ¿quieren sonreír? Pues que sonrían. En la guerra, las flores son algo delicioso. Cuando se está lejos de ellas, se desean. Y al estar acariciándolas, las flores llenan vacíos que debían ocupar las mujeres.

Una noche, como otra cualquiera. Encapuchada, en un mar sin estrellas. Son las 4,50 de la madrugada. Pronto vendrá el día. Los camiones caminan lentamente, como si estuvieran desperezándose.

Nos recibe el tiempo de la noche, con su frío normal de tierras frías. Estamos en tierras leridenses cercanas a los Pirineos.

Chiloeches — un cabo de mi sección- se había quedado admirado ante estas escasas estrellas. Él es cabo de la «motorizada» - los siete mulos de mi sección-y solo ama dos cosas en el mundo: las estrellas, las estrellas rojas claro, y los mulos.

Me he tumbado hace unos diez minutos. Estoy cansado del viaje. Esto es un caserío, y desparramado. Unas casas y un pajar aquí y otro allí. Así, unos cien metros cuadrados.

La noche me anima. El frío que sentimos, entretiene. Los soldados van a dormir a unos pajares.

Se oye una frase que tiene mucho de poética: «esta noche huele a verano». Es cierto. La cebada y la tierra despiden sabor primaveral. 


\section{3-mayo-1938}

Hoy me he ido a pasear un poco. Con Núnez, con Bernat, con Evelio. Nos hemos acercado a un puentecillo, por donde deambula una caricatura de arroyo. Un arroyuelo raquítico, delgado. Hay una carretera con chopos, que son dedos índices del campo. Y señalan a cerros pequeños, menudos. Evelio tiene una salida magnífica. Al materialismo descarado de Bernat, opone su parodia literaria: «ese cerro tiene la cabeza rapada como un tiñoso" ¿Comprendéis? Esta frase es en burla a mis deseos de hacer agradable las palabras. Y es que Evelio gusta de que le lea mis poemas. Y luego los aplica. Sacando símiles oportunos. Pero - y esto a veces, claro- también le gusta hacer gracias inoportunas de ellos.

Hay gran movimiento en el campamento. Todavía no sé como se llama el pueblo. Cervera está a unos $5 \mathrm{~km}$.

Tenemos distribuido el caserío. Núnez tiene sus hombres en un pajar que tiene $2 \mathrm{~m}$ de cama. Sus soldados duermen allí cómodamente. La paja es un excelente colchón.

Lo gracioso ha sido cuando Fermín —el sargento de la 3. ․ - ha sentido un ratón sobre sus narices. ¡Qué rápido se ha levantado! Encendida la luz, qué gracioso ha sido cazar al ratón entre la gran cantidad de paja. Todo el personal movilizado en la busca y captura del dichoso ratón. Aparecen los refranes castellanos y todo el mundo lo goza. Nos reímos de lo lindo. Es que son las cinco de la mañana, no os vayáis a creer.

Esta tarde salieron varios camiones con muchos $\mathrm{km}$. de circuito. Va a haber trabajo. Creo que Herrera, solo él, tiene que tirar $30 \mathrm{~km}$. de línea. Este bullicio es bueno. Señal magnífica que anima. Y la tropa está en una moral excelente. Además, tenemos a los del batallón Especial de Ametralladoras con nosotros. Como llegaron antes, han ocupado varias casas. Pero son buenos camaradas. A mi me ha afeitado su barbero, que actúa en el E.M.

Hay varios trigales - o campos de cebada, que en realidad no los sé distinguir desde lejos- donde las olas verdes se suceden, movidas por el airecillo que corre.

He visto a Marco. Es delegado de nuestra Compañía. Y ahora reparte prensa y unos folletos del Coronel Barcino sobre la batalla del Marne que están muy bien. 
De manera clara y concisa explica aquellos memorables días en que París se aturdía bajo la presión de la inmediata avanzada alemana. No puedo por menos que acordarme de Madrid. ¡Aquel noviembre de 1936! Sin pensar en fechas, surge fuerte el día 7. ¡Aquella noche! Mi padre estaba con las milicias Vascas, en Boadilla del Monte. Avanzaban los fascistas hacia el Pardo. Trabajaron bien nuestros soldados. La Brigada Internacional intervino formidablemente. Y se contuvo la avanzada enemiga. Vino la tranquilidad a casa. Una mañana, a eso de las 10, llegó mi padre. Con barbas crecidas, con el makuto repleto de patatas. Los besos, aquella hora de regreso, supieron a más cariño que nunca.

\section{5-5-38}

Las horas van circulando con su igualdad monótona: Aún no hay nada nuevo. Completas ideas en su semejanza. Los alrededores que circundan San Pedro del Arquells - San Pere del Arquells- siguen intactos. Nuestra vida humana está a tono con la vida vegetal y con los periódicos. Continuidad.

Ayer estábamos trazando sobre un plano el tendido de unas líneas. Y veíamos todo tan claro: ¡hasta el designio de nuestra juventud! ¿Cómo poder comprobar que somos los más excelsos jóvenes — sí, lo mejor de hombres sanos- acunados por un ímpetu de independencia y renovación? Apenas el sol cambia. Y, sin embargo, somos los más excelsos jóvenes.

Lejos, suenan baterías pesadas. Allí está la línea de fuego. «Notamos», que el frente está lejos.

«Cae» a muchos kilómetros de aquí. Pero todas estas circunstancias — ¿buenas?, ¿malas?_- permiten algún sosiego al espíritu. Y, a veces, se piensa. Yo he pensado estos días. Sacando conclusiones definitivas. $\mathrm{He}$ una: la de nuestra fuerza como fuente juvenil madura. Naturalmente. Acabo de leer unos ensayos de Stefan Zweig y «El teatro Político» de Piscator. Y me aplomo en mi idea. La muchachada juvenil española representa el cielo más puro que hoy cobija ansias humanas y vividas del vivir colectivo. Miramos en dirección al sueño español de Lope: vivir en paz, al N.E. que dirigen mis ojos, camina allá. Y veo brazos solidarios, y trabajo enaltecido, y vida hermosa y dignificada. El título más bello que yo le pondría es éste: «humano o humanos». 
Pasamos la tarde en prácticas. Los «nuevos» — soldados chavales del 40 y del 41 - se suben a los postes. Suben ágilmente unos; los más, no pueden con trepadores. Tienen «miedo». Y eso que dice Fermín que «los palos no hacen daño».

Pero la reflexión de los muchachos es sencilla: el que no sabe, puede caerse; el que se cae, puede hacerse daño; nosotros, que no sabemos, podemos caernos, luego podemos hacernos daño. ¿Veis lógica más fácil? Y claro, su silogismo triunfa. Sólo momentáneamente. Los sargentos y los soldados «viejos» —veteranos ya, con victorias como Brunete, Belchite, Teruel, en su carne y en sus huesos y en sus piesanimando con voces claras y optimistas - voces de guerra- hacen realidad el valor. Plasman el miedo en huída. Y los muchachos suben.

Amenizando la tarde, Tamayo nos regala una de sus magníficas "charlas». Tamayo le «echa mucho teatro al asunto». Es andaluz, de Vejer de la Frontera, aquel pueblecillo gaditano que se levanta para ver mejor cuando sale el sol. Aparte de ser cuentista — según sus compañeros- tiene un índice temperamental de lo exceso.

De todos modos, es buen muchacho. Trabajador. Voluntarioso. Decidido. Además, es buen antifascista. Estuvo con los «fachas» y se pasó a nosotros. Por verdadero ideal. Allá dejó su familia y su novia. Pero es que la fuente de independencia que llevamos dentro puede mucho. Ayudada por sentimientos de entraña españolísima, popular, puede más que todo. Es fuente sincera, íntima voz.

Ahora, cuando la ofensiva fascista por el este, Tamayo ha pasado sus excelentes peripecias y calamidades.

Con su cara rojilla y sus ojos agilísimos, está contando lo de Teruel. Tiraban que era un gusto los desalmados moros. Y allí Tamayo - que entonces era cabo, y ya luce sus insignias de sargentosufriendo las de Caín para colgar una línea bajo el viaducto. ¡Ahí va uno! ¡Paf! Un pepinazo que estalló cerca. Ya pasó. Uno de su escuadra avisó a tiempo. Pero la cabeza queda aturdida. No hay tiempo que perder. Para ganar nuestra guerra hay que poner al máximo la voluntad, la inteligencia y el esfuerzo. Tamayo hizo acopio de todo y se lanzó bajo el viaducto. Ya está hecho. Veinte minutos malos, malísimos. ¡Me cago en Dios! —dice (y esto lo dice él. Yo no podría decir jamás blas- 
femias)— las pasé «moradas». Trabajaba allí debajo, igual que se saca agua de un pozo.

Los nuevos camaradas de lucha escuchan con interés. Claro. Les parecen novelas. Pero ya, ya vivirán todas estas cosas. Y entonces no será lejanía, sino realidad palpable.

Otro día, fue formidable. Después de un ataque, quedaron muchas bajas por las calles de Teruel. Pero Teruel era nuestro. Lo defendíamos como rocas. Cuando vino la noche como una pizarra negrísima, imponía - es la verdad- circular tranquilo. Olía a muertos y a pólvora quemada, explotada. Y hubo que reparar una línea. Los del seminario tenían máquinas y no se podía trabajar con linternas. Trabajamos a oscuras. De pronto, uno dice: "Cuidado, aquí hay bultos». (En la guerra, de noche, todo son bultos, y bultos enormemente sospechosos). Tamayo para a la gente y avanza solo.

Silencio y quietud del pulso que era agitado y nervioso. No es nada: Nos avisa. Y sin esperarlo nadie, dio un brinco fantástico. Enseñaba sus manos. ¡Qué cara puso! Había tocado muertos achicharrados por la voladura del Convento de Santa Clara. No pudo estarse parado. Cogía papeles, daba vueltas. Su superstición y su asco hacia aquella carne chamuscada y pestosa no le dejaba quieto. Hubo grandes risas y brindis por los falangistas muertos en defensa de algo flotante que desconocen. Verdaderamente, hasta nuestros soldados más sencillos no se explican cómo los fascistas luchan ¿Por qué? He aquí la interrogante de Maïakovski en su poema «¿Porqué combatimos nosotros?», cuando la guerra europea. Es cierto. El virus doloroso de la muerte no puede quererlo nadie.

Sólo los equivocados capitalistas y los necios traidores. La alegría en la lucha de nuestros soldados - Infantería, Transmisiones, Artillería, agotados - se refleja en la canción popular. «Cantando a la muerte van...». Cantan su vida, defendiéndola de la muerte. Y la muerte sería la victoria impopular, falsa.

Esta noche del 25 de mayo, soy feliz transitoriamente. Tumbados en nuestros colchones requisados, se escucha música. Sí, música. Algún vecino de este pueblecillo - mejor dicho sería aldeíta - tiene un receptor de radio. Sus notas son claras, rasgadores del tizne sin luna de la noche. Bernat aplaude la música — ahora tocan un «fox» y él tiene un oído 
excelente- También Núñez tatarea. A eso de las 12, oímos el parte de guerra. Como todo lo clásico: sin novedad. Escaramuzas sin importancia (claro que este "sin novedad» representa, cuando menos, algunos muertos, algunos heridos, algunos lugares deshechos...).

\section{6-5-38}

El primer trabajo que tengo que realizar aquí. Son las 4 de la tarde. Sol y campo. Montamos en un camión, con $20 \mathrm{~km}$. de cable y 2 pelotones. Dejamos atrás San Pére y canta alegre nuestro bullicio. La carretera rebosa de gente. Está «la motorizada». Vehículos, armas, soldados, obreros de fortificaciones. "Se masca algo, y gordo». Todos sentimos «un picorcillo». ¿Es el deseo de luchar, de atacar? No puede saberse eso.

Hemos pasado por Cervera, Tárrega, otros pueblos más pequeños. Hacemos cola para coger gasolina. Pasan 3 chatos sobre nuestras cabezas. Y la alegría es pañuelo que vuela y saluda (¡Cómo sonríes ahora, ¡eh! gloriosa).

El tiempo, bueno. El pecho, cálido. ¡Atacamos!

Banderines catalanes juntos al valor fuerte de las banderas de las Brigadas Internacionales. Voluntarios y «viejos». Diezma dice que «esto es grande». No sabe expresarlo mejor. Pero ya está bien. Lo ha dicho todo.

Zumbamos - a lo que puede zumbar un «vusky», a $50 \mathrm{~km}$. por hora- hacia Tornabous. Y en medio de la carretera, rota, sola, desdichada, una guitarra. ¡Ya no traerá notas musicales! Es todo un símbolo. Su dueño tocará ahora la ametralladora, soñando su guitarra. Su dulce guitarra. Las sonantes que se olvidaron. ¿Comprendes esto, amigo mío andaluz que ahora eres «fascista»? La música, como placer de cosa vieja ¡Qué pena y qué rubor! Guitarra rota, con las cuerdas como embrollo de hilos.

\section{7-5-38}

¡Qué mala suerte! Hemos empezado a tirar la línea hasta el observatorio - desde allá, desde Castell del Remey- y empieza a llover. ¡Y llueve de verdad! Íbamos formidables. En una hora, cerca de $4 \mathrm{~km}$. y eso que es a campo traviesa. 
La línea va «pitando» formidablemente. Chapoteo constante y falta de material, nos estropea el resultado. Llueve fuerte, con temblores rígidos de agua. Esperamos que nos traigan más bobinas. Así, mientras, debajo de un pajar, con la lluvia a cuestas.

Por medio de un control logramos sea más rápido el envío de material. Sigue la lluvia, pero ya más débil. Entre barros, sonando potente la artillería de tiro rápido, terminamos nuestro trabajo. Al pie de un cerro, en unas covachas, está la central. Y allí, nosotros, comiendo y descansando. Manjón ríe y ríe, además de dar manotazos. Está sin lavarse aún. Es del comité «antihigiénico».

Después, abajo, en el destacamento. Ya cae la tarde, con su velocidad lentísima de sol. Vienen unas cuantas «pavas negras». Y Marín, el pobrecillo tímido — es soldado de la escuadra de Mora- echa a correr.

Su plato, pegado a la cintura, reluce. Le gritan otros soldados. Él se asusta, se atonta. Y hay que ver lo inoportuno y lo inconveniente que es asustarse a destiempo. Creo que será el infra-consciente, dominado por el instinto de conservación. Han tirado lejos. Unos ruidos abriendo entrañas al suelo. Humo, polvo denso y ocre y grisáceo. ¡Ya pasaron! Malditos facciosos criminales, grita una tiniebla a los que cree ella. No les vendría mal una maldición de gitana auténtica.

\section{9-5-38}

Pasamos los días en esta central, tranquilamente. Y tenemos buena suerte. Filete, el favorecedor n. ${ }^{\circ} 1$, nos ha traído huevos. No sé de dónde los habrá conseguido. ¿De Ibars? No, más lejos. Filete es todo un abastecedor fino. Trae huevos y vinillo blanco imponente. Esto alegra el cuerpo. Entra el blanco como las propias rosas. ¡Eh! ¿qué os parece, compinches de la retaguardia? Como dice Recena: Quien quiera peces, que se moje de veras (y no hay más...).

Hoy he leído un periódico atrasado. No está mal orientado. No sé como se titula, pues le faltan páginas. Leo una «Arenga» de Parpias. Dice que los combatientes llevan «el viento de España en los hombros» y «los ríos de España en las venas». Yo digo más. Yo canto que los hom- 
bres españoles son fuente de independencia en sus entrañas. Y las entrañas son más que las venas y los hombres.

\section{2 noche}

(No tengo sueño. Aprovechando que tenemos luz eléctrica, y bastante buena, escribo un poco. Releo lo anterior. Y veo claramente que no hay ligazón en lo escrito. Son «notas» demasiado rápidas. Quizás, algo sosas. Pero no me pesa. Son claras y sinceras. Guerrilleras, que diría el sargento gordo Virgilio. ¿No lo conoce todo el mundo? Pues claro que sí. Es medio literato, medio psicólogo, medio padre de los demás sargentos. Sí, papá Virgilio es buenazo, como él solo. Ha calificado de aceptable las cosas que ha leído mías.)

Hace varios días, lo menos una semana, que no he tocado el «block». Todo es aburrido. Replegar líneas, levantar la central, viajecillos en camión. Total, más o menos, lo de siempre, lo natural.

Estamos en una fábrica de Tárrega. Bueno, en las afueras de Tárrega. Se está bien. Sin agua, y sorbiendo cantos y vivas de la «motorizada», que pasa por delante nuestra. (En estos momentos, Evelio, que es un «besugo oricular» según propia definición, me está fastidiando. No hace más que pensar en «ellas». Y yo pienso más que él. Nos hemos juntado el hambre y las ganas de comer). Pasan más camiones. Y una chavala magnífica. Sanota y campesina. Todo un panorama ¿verdad, Evelio?

El mes bisectriz del año ha abierto su calendario. Mejor dicho, su mensnario. Junio nos va volcando sus jornadas. No sé que fecha es hoy. Y eso que nos vamos. Preparamos los «trastos», y ¡hala! Atrás Tárrega — ¡ay! La niña del mono, qué bien estaba- y nuevas carreteras delante de nuestros ojos. Pasamos por Igualada. Está presentable. Me gustaría pasar en este sitio una temporadita. Y sino en Valls, por donde atravesamos ahora, y que tiene unas chicas formidables. Cantan los camaradas. Un catalán, recluta, dice que las chicas de Valls son lo mejor de Cataluña. Nos alegramos automáticamente. Sin decirnos nada. Recorre el cuerpo un vigoroso empuje de ilusión. Y alguien exclama: «que venga Freíd con sus cuentos del psicoanálisis». 


\title{
10 junio
}

La fábrica. Ladrillos volteados, boca arriba y boca abajo. Nerviosismo en la mampostería. Al lado, como arrullo, las aguas clarísimas del Francolí.

Alcocer se quedó atrás. Con su iglesia medio románica ¿porqué decir románica? Prefiero el claro romántico del placer y del reposo, de la admiración.

Nuestro lugar es excelente. Los teléfonos brillan por su presencia inútil. (Si me oyen, me pegan. He querido decir que existen sin uso inmediato y actual). Molins de Cubell. Nombre catalán, auténticamente catalán.

Aquí domina la paz. Agua del río, agua de la piscina.

Os contaré un «hallazgo». Han venido varios soldados de mi Sección a decirme que «encontraron arqueología, cosas antiguas». ¡Poco contentos que vienen!¡Es para Guereña, para el teniente Guereña! Nada, que no tengo más remedio que caminar. Y lo hago. Voy a ver lo que resulta de la excursión. Entre Picamoixons y Valls.

Casa deshabitada, ruinosa, "algarrobada», como dicen mis soldados de Yébenes. Al costado izquierdo, el Francolí, acariciando las piedras redondas del puentecillo romano. Las limpia y pule con su erosión modesta. ¡Ay! Las horas que cruzaban la linde del tiempo. «¡Cualquiera tiempo pasado fue mejor...”. Sí, compañero Jorge Manrique, tenías y tienes razón. Tu copla es esto: viejo puente, viejo lugar, viejo río, vieja casa.

Y la nostalgia histórica acude presta. Un banco pétreo, con un torso desnudo, también pétreo. Nostalgia, historia, poesía. Me siento en el banco, sumamente agradable. La piedra y el recuerdo. En el torso, esta inscripción:

\section{VALLS}

\begin{abstract}
ALS MARTIRS D LA PATRIA
LO DIA 25 D FEBRER D 1809 MORIRON

EN AQUES CAMP LLITANT CONTRANT

EXERCIT D'NAPOLEÓ.
\end{abstract}

\author{
ELLS
}

25 FEBRER 1909.

(eso es todo. Guerra y copla. Jorge Manrique y yo). 


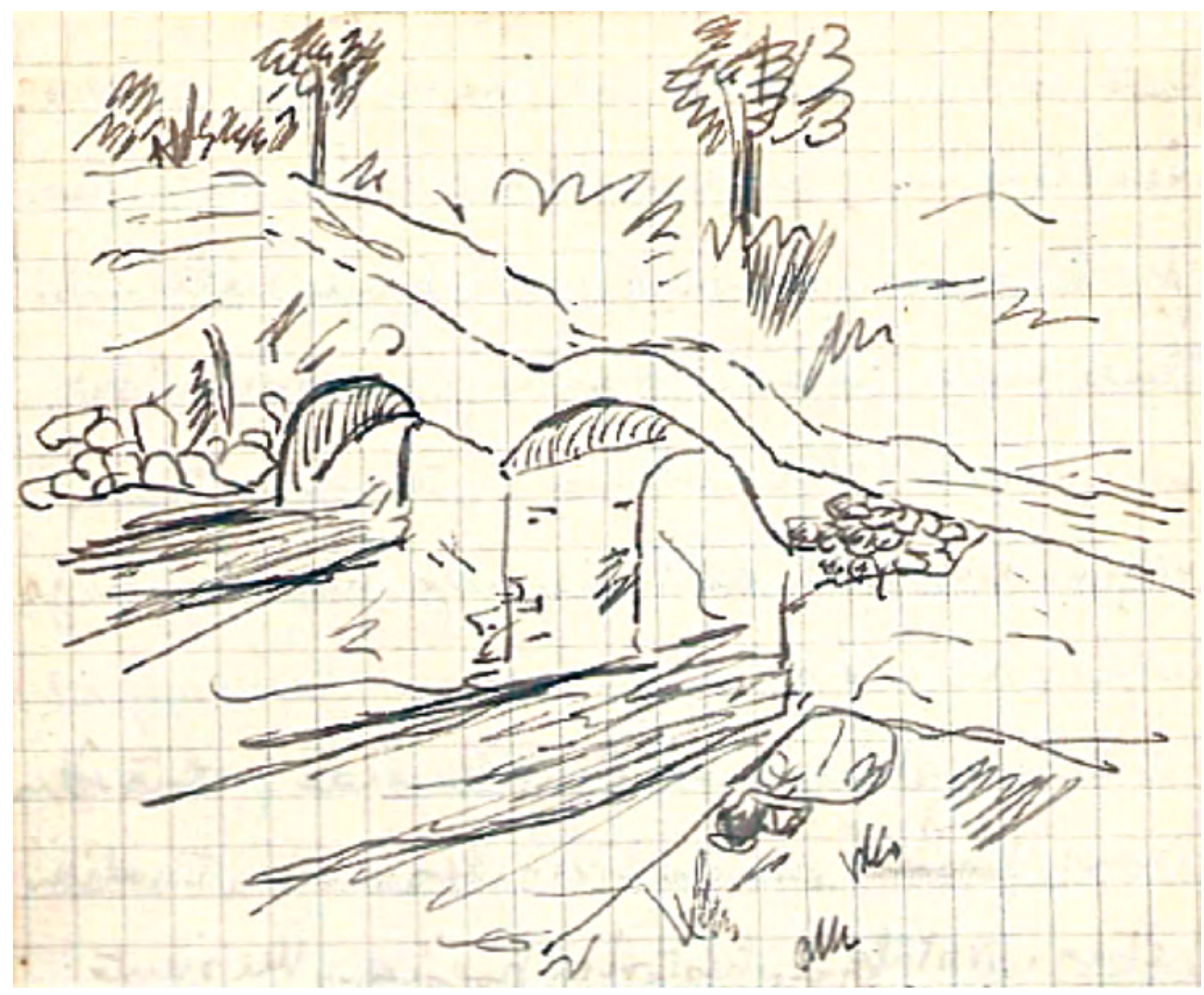

El original queda allí. Entre arbusto y olivos. Dibujado sobre la canción del V Regimiento. Recuerdo de la nostálgica hora. Explicación: Evelio quiere dibujar algo para mis «notas». Es buen índice, porque significa que está de buen humor. Y el estar contento en una posición, cuando se está destacado, es algo formidable, sano. Si el optimismo fuese la tendencia política internacional, iqué feliz sería la humanidad!

Además, también estoy contento. Hoy parece que lo estamos todos. Primero vino Marco a traerme una carta — sobre pequeño, letra pequeña- de Rosita. Luego ha venido otra vez con dos cartas para mí, de Mario y de casa. 


\section{JULIO. POBLET}

La historia aquí, personificada con toda su duración y con las piedras del Monasterio de Poblet. Además, las aguas buenísimas del Balneario. Esto era lo más importante para los turistas y los enfermos. Lo demás, toda la formidable lección de la historia y del tiempo, se queda para los que «estudian». La vida no necesita filosofía histórica. Exige aire, y campo, y «chalets» de veraneo. ¡Absurdo criterio! Pues así viven la mayoría de las personas. ¡Absurdo, absurdo!

\section{3 julio. 7 de la mañana}

La mañana se aguza como lanza. Son madrugadoras horas. Tiempo de verano, sol tempranero.

Caminamos a paso largo. La Compañía tiene que hacer sus prácticas. Yo, estoy de oficial de semana. Y voy con ellos, claro.

Los muchachos cantan. Animan el campo de viñedos - famosa uva y vino de Espulga de Francolí- con su canción vieja. Vieja, sí. La del 5. Regimiento. Casi todos estos muchachos proceden de allá, de Madrid, del 5. ${ }^{\circ}$ regimiento, después $5 .^{\circ}$ Cuerpo. Y sus venas guardan emoción de días archivados — pero no olvidados- que aún permanecen con el verde de lo vital y fresco.

Por estos parajes, no hay más remedio que admirar el arte. O negarlo. Una de dos. No se admiten eclecticismos. Todos nosotros divisamos las torretas redondas y cuadradas de Poblet, de su monasterio. Y nos deleitan.

Ahora, al cruzar la carretera —un poco más allá de la casa del cuartel General- vemos un trozo bellísimo. Campo y silencio. Un banco de piedra y un telón de verdura con rocío. ¿Se dormirían con escenas soñadas? No sé. Pero este recinto — paraje romántico— es fértil de emotividad como un río.

¿Quién no ha revelado su íntimo sentir de gozo con la mujer que se quiere? ¿Quién no ha explicado su sueño permanente de poseer la belleza del arte, del amor, del paisaje? Sí, es exacto. Verticalmente cierto. Es la edad impetuosa. El reloj parado en los 20 años. 
Bécquer estaría aquí. Sí. Bécquer estará con nosotros en las horas más cursis — por repetidas-y originales — por nuevas en afán- de nuestra vida: las horas del amor.

\section{5 julio. Mañana y tarde}

No sé lo que tiene este montículo, que me atrae. Está situado a espaldas de nuestro destacamento.

Subo todos los días. Por la mañana y por la tarde. Con sol y con sombras. Sobre todo, me gusta subir al atardecer. Caen, desplomándose -es rescoldo final del día- delgados rayos solares. Lejanas montañas se iluminan. Y el rojo de este cerrete de hierro brilla con tonos delicadísimos.

En el valle, como templo y como reposo, el Monasterio de Poblet. ¡Ay, Poblet, con tus claustros y tus paredes roídas por la vejez!

Aquí tengo que pensar, y forzosamente. ¿La guerra aniquilará el esfuerzo de la cultura y de los hombres que trabajaron por lo bello y sublime? No. Esta sensación de seguridad en la cultura y en el arte produce bienestar. (Grupos de soldados visitan el Monasterio y escuchan atentamente, sin gestos, las indicaciones históricas que hace el guía).

Llevo conmigo un libro de Stefan Zweig. Me gusta Stefan. Estilo liso y vibrante. Antes de la guerra sólo le conocía a través de las literaturas. Y no en todas venía su nombre. Sólo en las más recientes, abiertas a la realidad del mundo literario actual.

He leído casi todas sus obras. Y casi todas han dejado en mí un regusto de placer, de enseñanza, de admiración. En este libro que llevo en mis manos — «La lucha contra el demonio»- habla de tres poetas. Kleist, Hölderlin y Nietzsche. Los analiza con buril hondo. Saca a flote sus fibras poéticas. Y en la introducción existe este magnífico guión de estudio y crítica: «No hay arte grande sin inspiración, y la inspiración llega inconscientemente del misterioso más allá y está por encima de nuestra conciencia». 


\section{2 julio. Mediodía}

Sentado en la Sala Conciliar. Obispos, abades que yacen. Tumbas antiguas, con basamento pétreo. Diplomas en el suelo, guirnaldas de latín en las timbas.

¡Hermosa sala la Sala Conciliar! Faltan los colores en la vidriera. Son las 11'30 y no se ve bien. Quisiera que fuesen las doce de la noche, con luna penetrando por los ventanales amplios y bellos.

¿Podremos olvidar la sensación íntima y gozosa? Sólo sé que la muerte se siente huída ante esta presencia tan eterna. Yo no describo los arcos y los claustros del Monasterio. Sólo gozo su impresión.

Por la nave central. El rosetón, grande, amplio, allá, al fondo. Tumbas de reyes, de príncipes, de condes. Insignias de heráldica. Escudos y marcas señoriales.

Pero yo quiero expresar una duda que tengo y que podía ser una sugerencia:

$¿$ ¿Hay reminiscencias del culto a los animales, con motivo del descubrimiento de América y su colonización, con las iglesias coloniales -en el Monasterio de Poblet y en otros monasterios? En los bajorrelieves se ven figuras animales. Puestas con toda intención. Destacan leones y cabezas de tipo azteca y maya.

¿Será algo de arte y símbolo? ¿Símbolo americanismo en Poblet? Decídmelo.

¿Es un vago recuerdo del influjo bizantino en los templos románicos? Pudiera ser. Hay ángeles feos y desgarbados, monstruosos, casi con figura de animales. Alberti ha escrito «sobre los ángeles» y los encuentra de mil maneras.

¿Qué es lo cierto? Me inclino por el que sean reminiscencias del culto a los animales, en forma más pura, hecha arte en su divinización naturalista y débil. 


\section{Agosto 38}

No sé cuanto tiempo transcurre sin que me acuerde de la libretilla de notas. Pero es exacto. Domina la tremenda verdad de mi abulia. No tengo deseos de escribir. Ni de recordar los estudios, mis «cosas de antes». La universidad, aquel viejo caserón con griterío constante y con luchas de la F.U.E y F.E. Aquellos días, en que los exámenes rumiaban y rumiaban mi entusiasmo. El sueño era el que sufría las consecuencias. Había que aprobar...y se aprobaba.

Bien, nada de eso tiene importancia. El caso es que estamos en operaciones. La segunda, desde que fui destinado al Ejército del Ebro. Y se trata ¡nada de menos! que del paso del río. Del Ebro, «brazo gentil del Norte y Cataluña», como lo dibujé en un poema.

Pero no tengo noción del esfuerzo realizado. Solo sé que ya está hecho. Y que participé en él, desde el primer día del «asunto». Ya el 26 estuve en Vinebre. El 27, pasé el río. Nada más. No quiero apuntar más detalles. La prensa, ahora, las hemerotecas después, me devolverán la memoria y el verdor de estas batallas.

\section{2 agosto}

La aviación, encima. Fuego de contrabatería, muy nutrido. Hemos tendido una línea y dos chicos —soldados- nuestros, heridos. Suena la artillería con estúpida insistencia. (no sé, pero hoy, encuentro - yo creo que siempre es así- que todo lo que ocurre en la guerra o es estupidez total o tiene una participación elevada de lo estúpido).

Vocerío de muerte. Artillería: Balas «fachas» por los senderos desperdigados del monte.

Y curioso, ¡canta un canario! Sí, en Venta de Campusines. Un matrimonio, que nunca se movió de su casa. De la Venta. Aquí, famosa Venta, cruce de tres carreteras, nervio forzado de todo el sector. Bombas de $500 \mathrm{~kg}$. Hoyos y hoyos. Pero tremendos. La 35 División, lejos. Martin Medina, Vera, Escobar,....allí.

(Me acuerdo de mi niña. Carmen. Mi vida, Menchu. Tú, tan a distancia. En el «foro»: Madrid, mi casa, mis padres y hermanos, mi Carmen). 
Esta mañana, en Corbera (el frente allí, a $2 \mathrm{~km}$. de Gandesa, enfrente) estuve hablando con una chica «roja» que ha estado con los «azules». Cuenta cosas curiosas. Muy simpática e izquierdista.

Son las 5 de la tarde. No sé cuantas horas llevo sin comer. No es por falta de comida (la hay, y con relativa abundancia. Es el trabajo, la ofensiva, la emoción, la nostalgia... es todo, la dichosa guerra). Agua y sólo agua.

¿El estómago se quejará? Hasta que resista.

Entre las cosas que he encontrado por este sector, tengo varios periódicos «franquistas». Estoy leyendo «Heraldo de Aragón». Miguel Artigas escribe unas notas. ¿Sabéis quién es? Era director de la Biblioteca Nacional, de Madrid. (Su croquis psíquico-físico, era, más o menos, así: Pequeño, arrugado, con sonrisa irónica de estatua muerta. Su paso menudo y corto, entre las mesas de estudio de la B. Nacional. Caminar de cazador, y ojillos de detective. Y la inteligencia suya tenía que utilizar pilastras, para que se pudiese ver).

\section{3 agosto}

Otra vez en el túnel, de Ascó.

La ocre belleza del pueblo refuta obscuros presagios de la soledad. Del hosco y amargo silencio. Ascó, bruñido por el río, lo limpio y curioso. Se lava cara al monte y al Ebro. Lejanas, nubes rojizas y acaloradas por el tardo calor del día. Y horas tranquilas, modestas, francas. Sin pesadumbre. Huidas de la aceleración.

Ascó limpio, chiquito. Como cariño pueblerino su vida, su amor, su apariencia, su sensibilidad. Monte, ribera, río.

(Y Ascó, mientras tanto, con sus techos rotos y su embriaguez de bombas y de obuses. Con silencio de pequeñez y de acoso mortal).

La higiene es un definidor magnífico. Nadie quiere ser señalado por sucio. Viene prontísima la sarna. ¡Ah! y la sarna no es enfermedad de hospital, como lo afirma Sanidad diariamente. Batres, con su traje de baño - para bañarse y para vestir- parece un «hombre cavernario». 
Barbas y sol, botas y piel tostada. El Ebro está aquí, lavándonos en su orilla derecha. ¡Ay, el Ebro! Quién lo pasó y quién lo pasara.

\section{4 agosto}

Hoy he nacido. Una bomba de aviación, encima de mí. La suerte, en actualidad. El chofer, herido; yo, ileso. Venía un solo avión, una sola bomba ha tirado, y nos ha tocado a nosotros. Parrilla ha gritado: ¡Teniente, Teniente! No ha pasado nada. ¿Qué es la muerte, así, silenciosa? Un fluir de silencio y eternidad equivocada. Yo no sentí la bomba, ni nada. Hundido por la tierra y la explosión. Allá, acerca de Camposines.

¿Y qué? ¿No han matado a Núñez? Aquí tengo mi tarjeta, devuelta. Lacónica, fría, delgada. Dice: «desaparecido» Y ya está.

\section{5 septiembre}

He escrito un artículo para el mural. El 25 de julio cruzamos el río. El Ebro. Y Ya son 60 días los que permanecemos en esta margen derecha. 60 días con 60 lunas.

El día amanece húmedo.

Pálidas nubes, con belleza de lo solitario.

Techo en gris plata, con lluvia cernida

Que acaricia los labios y los árboles.

¿Cómo sueña la poesía!

Recortadas montañas y verdura fresca.

Al hablar suena la voz como hueca. Se extiende, magnífica, en la vaguada.

Olivos y troncos retorcidos. Brisa que se anhela. Rumores que no se oyen.

Pálidas tierras. Pinceladas húmedas. 


\section{1 enero 1939}

Otra fecha más nueva. Más absurda, porque pasa la vida y el tiempo y no sabemos si hemos vivido.

No es señor el apetito. Hay algo más hondo y exacto en su acuciar.

Los amigos no existen. Y funden su fuerza —en mis días- el sol, el campo, el agua, el fuego y el mar.

No quiero escribir nada de estas duras semanas. Ni de las próximas. Cierro las páginas de este viajar errante y cruel, después de leer la verdad.

\section{1 enero 1939}

San Hilario de Sacalm. Cerca de Santa Coloma de Farnés. Un magnífico castillo-palacio. Fue residencia (propiedad) del marqués de Monsolís y ahora, vivió allí Luis Companys.

Salones excelentes, formidables. Arte, arte. Cuadros, arquetas, bargueños. Tapices, los dos que lucen con sus insignias heráldicas en la escalera central, que brillaron en la Exposición Internacional de Barcelona. A mí, me maravilla esto. Ya conozco palacios semejantes $-\mathrm{y}$ mejores - como el palacete de Liria, el de Medinaceli, el caserón viejo y artístico de los Marqueses de Santa Cruz... Pero este me gusta y me encanta. Hay un algo agradable y cariñoso. Es gusto y arte.

Lo han reconstruido. Ventanas góticas en fondo moderno. Tres torretas y jardín y puente de entrada.

Un salón de estar, delicioso. Con grabados de autores ingleses verdaderamente buenos. Marinas y cuadros de monteros. Es bonito y luego, la biblioteca. Nada nuevo. Viejo. Incunables, diplomas y manuscritos. Hay una edición, reciente, en catalán, de las obras de Ausias March que es excelente.

Además, en este saloncito hay fuego. Cocina de invierno y butacones cómodos. Al lado, el comedor, con su cocina de madera Renacimiento y la araña de bronce oscuro.

Llueve, y la tarde es preciosa. Sobre los ventanales con guerreros como vidrieras religiosas- el chapotear del agua gris de Enero. (Y he 
hecho un pequeño inventario de todo este tesoro; hay que impedir que se rompa. Es de España y gane quien gane, debe ser tesoro de España).

\section{3 febrero}

En Camos, al lado de Bañolas.

Son las 11'30 de la mañana. Un sol que me besa, atravesando los cristales sucios de la habitación.

Tengo que pensar a la fuerza. ¿Qué será de mis padres y hermanos? En Madrid ellos; yo, aquí. He «motorizado» mi equipaje y solo llevo un makuto. Unos libros, un poco de ropa y ya está. No hay más. Esta velocidad de viaje lo requiere. Kilómetros y kilómetros agolpados en los riñones. Y menos mal que vamos en «S.M.C.» Recuerdo las caravanas de carros, de mujeres y niños, de soldados hechos polvo, y me da pena. (Odio la guerra y sus consecuencias. Es horrible y fuertemente sentimental y nostálgico.)

Pero dejemos eso. Lo exige el soma y el estómago.

El verde es suave y el sol, cernido. Es una escuela. Pobre y rural, descuidada. El maestro, marchó con las quintas. La maestra se fue, y vive en Bañolas. Soledad fría.

Lo que me interesa es la casa hermana. Catalana Típica. Y en el frontis de la puerta, la piedra central con una fecha: 1642. Es el sello de los libros: «Propietat Ferrer. Any 1642».

Las masías son evocadoras y terriblemente familiares. Sus almiares a medio gastar. Y la cocina amplia, cobijadora.

¿Qué soñar en gritos de muerte y huida? Mirad otras cosas más exigentes y más reales: los niños vienen a buscar sus libros y sus pizarras y sus lápices de colores. No he podido remediarlo, y quizás con un hábito reconcentrado de otras épocas, he cerrado la puerta y he escrito con tiza, en su madrea marrón, esto otro: «Studi».

No merece la pena olvidar la poesía. Estas escenas son poéticas. Llevo conmigo las «Cien mejores poesías de la lírica castellana» y junto con Astudillo y Gonzalez — los dos buenos amigos, íntimos y algo másleemos versos y recitamos a Bécquer. 
En escenario elegido. Nubes en techo azul, y paja amarilla en casas blancas con balcones abiertos. Luz, vida, guerra y sol.

También leí, anoche, a Machado. Su teoría peregrina de Mairena, embriagado con la Máquina de Cantat. ¿Acaso morirá el poeta sólo y personal? No, no.

«Mientras haya una mujer hermosa,

habrá poesía.»

Y escribir lo anterior, me parece ridículo. Sí, porque, ¿quién sabe si estos cañonazos que suenan no romperán estas nociones?

\section{5 febrero}

Ayer — ¿no fue ayer?, no sé, quizás fuese antes de ayer (anteayer)— cruzamos por Bañolas. Lugar de estanque y chocolates. Sí, ¿no sabéis? El chocolate Amatller, buenísimo. Cuando era niño, en mis días de ingreso al instituto, coleccionaba estampas de futbolistas que venían en las pastillas de chocolate.

Ahora, ese sabor de infancia me atrae con más fuerza que nunca. Con poder evocativo - ¿Qué venga Bergson y aclare los problemas de esta categoría - ha surgido aquel tiempo. Corrió el almanaque, y yo he crecido y he cambiado. El pasar por la vida es una anécdota.

Cerca de Figueras

Los montes, con abrigo blanco — sí, allí enfrente el Canigó, picudo y joven-. Los Pirineos Orientales que nos cercan con sus pasos de frontera.

Siento a mi alrededor —en los compañeros, en el ambiente, en el aire y en las carreteras- algo raro, extraño. La gente no es la de siempre, no. Hay un hálito de nerviosismo y preocupación. (Es lógico. Nadie sabe nada. Y a todo el mundo le interesaría saber algo, mejor dicho, mucho).

Hace un momento, cantaba yo. Y el «pagés» de la casa que habitamos, dice que estoy contento. ¡Contento! Qué sarcasmo. Por dentro anda la procesión, me ayuda el estilo refranero de Castilla. No se admite 
la risa y la alegría. Rostros largos, como chopos delgados. Y un existir de preocupaciones.

¿Conocéis la casita que habitamos? Se sube por una carretera estrecha y muy transitada. Hay una verja de gallinero. El zaguán es sucio y poco amplio. Enfrente, la escalera. Las tijeras de cortar viñas, como adorno constante. Luego, la claridad. Una salita reducida, con tres ventanas y terrazas. La abuela, cosiendo. Y besos abiertos del sol ampurdanés.

El porrón de vino lo utiliza el abuelo. Su carga de años es un atentado a la infancia que se muere.

Pero la casa vive con un fondo de árboles y montes. Nuestra Sra. del Mundo, llaman en geografía local a estos montes verdosos de ahí. Y tras ellos, la nieve perpetua de los Pirineos.

Un día más. ¿Llegará otro?

\section{8 o 9 de febrero de 1939}

No sé ni la fecha que es. ¿Y qué importa eso? Algo más trascendental está ocurriendo ahora. Tampoco logro darme cuenta de la importancia tan enorme de los días que transcurren.

En fin, nada es definitivo. No sé si Barbusse o Remarque pensaron alguna vez en ello. Pero yo veo claro; y la guerra nuestra, en estas últimas consecuencias en Cataluña, lo atestigua así con toda su crudeza y miseria.

En Port-Bou. ¿Sí? sí, amigos míos. Desde Corbera a este lugar hay muchos kilómetros, ya lo comprendo. Lo exige la verdad y tenemos que reconocerlo. Vamos a pasar la frontera. ¿Vencidos? No sé; algo liquidados, sí.

Ya he cruzado la línea fronteriza. Y algo raro y maravilloso. Cerbère con sus luces encendidas. La noche brilla como una verbena madrileña. Porrones de luz en el aire. Resortes de agua mecidos en tranquilidad extraña a nuestra sensibilidad propia de guerra.

Todo me hace gracia. Es imbécil y tonto, pero es la verdad. Con toda su desnudez desagradable y molesta. 
Yo la acepto tal como viene. Fastidiándome, claro; pero aceptándola.

Después de no comer en todo el día, pasamos la noche en Perpignan. Un campo de concentración. ¿Cómo Alemania? Los gendarmes protestan de tal definición. Ya lo comprobaremos nosotros, que somos los «paganos».

Ha pasado la jornada nocturna. A las 3’30 de la madrugada me acosté. Y son las 6 de la mañana. Los senegaleses —esos negros de ojos risibles y tipo desgarbado de palmera mecida por el «simoun»— nos obligan a levantarnos.

Estoy cansado. Sin dormir. Sin comer. Falto de entusiasmo. Falto de casi todo. ¿Mi familia? Sí, en Madrid, sí... y no sé más de nada.

Bueno, en fila de tres. Parecemos prisioneros. Y ahora, en este barullo de filas y policías, los hermanos Vera, el comisario Arginio y Martinez Fuentes. Meses de no verlos. Todos aquí, en verdadera norma de feria. La gente francesa, por las calles, nos mira como bestias o bandidos.

Montamos en el tren. Perpignan adelante. En Elne se para. Nos esperan docenas de gendarmes con bayonetas caladas. Largas, que parecen postes.

Bueno, andando. Vamos al campo de concentración. Creo que a Argelés. Caravanas enormes y larguísimas. Hombres, mujeres, niños, militares, confundidos en rostros de sueño y de hambre.

Ya no cavilo. Ni río siquiera. Las francesitas buenas que veo, no me interesan. Nada me llama la atención. Se lo confieso a Tomás Vera. Y mis palabras son estas: la guerra nos hizo indiferentes.

¿Las nubes y los Pirineos nevados? ¡Qué risa! ¡Vaya cosa! Todo es fútil y grotesco. La guerra, sí, la guerra.

\section{2 marzo}

Ha pasado el tiempo como agua. Corriendo a más no poder. Y yo, sin darme cuenta.

Aquí, en esta "ciudad de arena y nubes», se consume el humor y el afán de pensar y decidirse. A pesar de todo, como he tenido un hallazgo 
— sí, el camarada Pedro Cecilio Sáez, con su edad consejera y su poesía y su latín y su recuerdo de los clásicos- de vez en cuando se charla charlamos-y se piensa - pensamos-.

Pero es en dosis. La vida de campo de concentración es horrible y asquerosa. Hay tedio y enormidad monótona.

Este Saint-Cyprien tiene fama. Su playa ya ocupó igual lugar en los años de la guerra europea. Los alemanes prisioneros vivieron a lo largo de esta playa sucia y fea.

He encontrado a muchos conocidos y amigos. De Madrid, de España. A Burgos, el escenógrafo. A E. Abril, el dibujante...

Ayer he lavado mi ropa. Por primera vez en mi vida. Y lo he hecho alegremente, cantando. Con un sol formidable y un airecillo divertido. Me duelen un poco los dedos, pero no importa. La ropa no queda mal. No bien del todo, pero ¡vaya!, aceptables.

(Pienso, después, cuando pueda, escribir un librillo de notas de campo de concentración. De refugiados en Francia. Título, uno curioso: «Días estériles» (no es cosa mía. Es una cosa sugerida, escuchada).

\section{9 abril. 5 tarde (domingo)}

Hace tiempo que pensé no seguir las notas. El tedio y la esperanza, me hacían remirar horizontes más agradables. Relojes que señalan la hora y discursos con noticias de sucesos concretos, me vencieron.

La familia allá, en Madrid. Acontecimientos del 6 al 12 de marzo. Inquietud. Y la terrible duda, con su signo exacto. ¿Qué será de ellos? No quiero imaginar nada malo. Me parece idiota aquello... y los resultados. Catastrófico todo.

He cambiado ya cinco veces de campo de concentración. Camp d'accueil le llaman al de ahora. Gurs, (Bajos Pirineos) a $80 \mathrm{~km}$. de Bayona. $\mathrm{Y}$ antes, en Perpignan, en Saint-Cyprien, en Barcarés, en Argelés-sur mer. 
¿Hiere la suerte? Así hay quien piensa todavía. Yo creo lo contrario. Pero, en fin, el dolor es orgullo cuando es dolor noble, justo, producto de acuciar de libertad.

Entre montones de cartas, al gritar en alta voz el cartero de la barraca, se oye mi nombre. ¿Remitente? La buena y simpática Águeda. No nos perdemos de vista. Y me alegro (ahora cantan unos aquella cancioncilla del Ebro, del paso del río, y todo es vieja melancolía). Águeda, su voz de «jueves valenciano», charlas por teléfono desde Barcelona, en fin, la vida grata de siempre.

Es domingo. Tarde francesa dominguera. La carretera general — «route de Bayonne» a $20 \mathrm{~km}$. Pero...sí, el pero existe. De aquí allí, alambradas triples. Parece esto el parque zoológico. Ellas -las francesas, «jeunes très jolies»-- paseando elegantes. Niños riéndose, y autos desfilando en «ralentí». Admirándonos, un gozo de fiesta gratis y original.

\section{9 noche; luna y estrellas}

Es deliciosa esta noche primaveral, clásica. Suelo imaginar con Sanjuán, el estudiante recién conocido y ya amigo de siempre, en comunidad y gozo de sentir y de pensar, en la mar callada. Terraza blanca con cerveza y murmullos de olas jadeantes. Abril y noche. Es ahora cuando la sueño. ¿Dónde mi mundo civilizado? ¿Dónde la sonrisa de juventud en romántico sentir de orilla marina? ¡Ay! Y ella tendría que ser rubia, cabellos suaves y largos, a ser posibles con ojos azulísimos y vestido blanco.

¿Cursilería? No, eso es emoción...y mis 22 años. Es la carencia de 3 años de juventud - la guerra- en mi vida. ¿La añoro? Por todo, sí.

Hay unos cuantos chicos con «chistu» y tamboril. Euzkadi en $500 \mathrm{~m}^{2}$. Y el recuerdo que se exalta. Suenan los pitidos «chistularis» y bien pronto bailan «esptadantzaris». Al compás de las estrellas bucea la alegría de jóvenes vascos.

Altos montes, el Gorbea, el Amboto, San Victor, con sus romerías, sus comidas, sus fiestas. Aquello era la dulzura hecha realidad. Verde y azul de noche. Verde esperanza y verde hierba. 
Aquí, encerrados, prietos en la barraca. Hombres ávidos de vivir, apretados en su dolor. Y lo que yo ansío es la vuelta al mundo, la inauguración de nuestra libertad.

Yo quiero la esperanza en su hábito de cultura. Lo demás, todo lo demás, es pobreza de espíritu. (Incluso este hojear de anuncios, en que diariamente buscamos alejar el tedio y soñar inéditas y posibles relaciones)

\section{3 abril. 10:30, nocturno}

¿Qué decir nuevo de este nocturno delicioso? «Nihil novum sub sole». Efectivamente, nada nuevo bajo el sol. Pero sí bajo las estrellas. Y es mi candor imaginativo en la música.

Figuraros un bello cuadro de la Viena de fines del siglo pasado. Flores y rostros arrebolados por el amor. Donde se cruzaron baladas de Heine y versos rotundos de Goethe.

Es con esta estampa como hemos encauzado nuestra charla nocturna. Avanzan las constelaciones con su carga de estrellas y puntos luminosos. Controversia de tonos azul marino. Evocación de músicas y violines.

Yo explico mi sibaritismo romántico y sensible cuando escuché «Vuelan mis canciones». Fue en Madrid, en mi querido Madrid, albergue de mis años universitarios y de mis poemas.

La voz sugestiva de Marta. Y mi imaginación, echada a volar. ¿Cómo? No sé exactamente como era. Pero sí fuerte, definitiva. La «célebre serenata» y la «Sinfonía inacabada», como decían en Cataluña.

Yo soñé, soñaba, aún sueño con aquellos acordes en mágica y humana armonía. Una sala inmensa, única, infinita, sin ventanales ni puertas. Aplastada y de longitud universal. Un espacio, mejor que una sala. Negro, azul, negro, azul. Y yo, sólo, allí. Absorto. Éxtasis de poema musical. De pronto, la melodía de Marta al compás de Schubert. Suave, primera canción de niño. Suave, con introito de potencia. Después, resonar de la «Sinfonía incompleta» y el «Ave María» en dominio del vo- 
lumen, del espacio, del tiempo y de la psicología. Yo, soñando, soñé, sueño, soñaré siempre con mi dibujo de estas emociones.

\section{4 abril}

¿Qué bonito está el cielo mojado! Acaba de caer un magnífico chaparrón. Y qué bello el paisaje con su humedad de adorno.

Las hojas, temblando aún, con la última gota de agua suspendida. ¿Qué bonito el cielo mojado!

La verdad es que resulta un poco inoportuno este acuciar mío de encontrar siempre poesía en todo. Incluso aquí, en este «camp d'accueil».

En pequeña conferencia polemizada he tratado de discernir analíticamente sobre la cultura, su concepto y su misión. ¿Cultura vital? ¿Cultural individual? ¿Cultura de masas? Creo que son cuestiones candentes. Y que tienen su ahondada raíz en principios filosóficos. Con algo de pensamiento político-económico. Pero, sobre todo, buril de filosofía.

\section{4 junio 1939}

Hoy, a las 3 de la tarde, fue la inauguración de nuestro «club-escuela». Nuestro, sí. Del Islote B. (Ah, pero si me olvidaba. Ya el 5 de julio, 5 meses preso. En campo de concentración).

¡Bah!, lo importante es nuestro esfuerzo cultural. Acaso Abadía se marche a España - le han mandado avales de su casa- pero dice que jamás podrá olvidar esta tarde «concentrada».

Música, czardas, serenatas, coro «basque», espadantzaris... y luego, la exposición.

Dibujos, poemas, fotografías, cosas de Mena y mías (y algo que se quedaba mudo: unas palabras mías sobre la cultura y nosotros).

Ya llega la noche. Y estoy cansado. Pero sin fatiga la imagen de nuestro «club-escuela». 
Cuartilla de la reflexión.

$\mathrm{Y}$ esta pequeña tregua en el aburrimiento diario es una gloria que tenemos que agradecer a la histórica Francia. Donde campea el tríptico de los Derechos del Hombre. Su amor al respeto, que yo admiro.

Mi fibra sentimental es agradecimiento a Daladier y su buen gobierno. En los días difíciles de febrero de 1939 elle, Francia solo, nos salvó el mal momento. Y acaso la vida, pues entonces el nerviosismo cundía en los de $1 .^{\text {a }}$ línea, aunque no en mí, pues yo era de Transmisiones y mi temperamento es siempre - o quiere serlo- sereno. En fín, la nación francesa ha demostrado su continuidad histórica de humana ética y buen corazón. Francia es honor y cultura e historia.

En la longitud histórica, también se ha visto un entronque cultural entre Francia y España. Honor, como escudo. Y hoy, al hallarnos en suelo del sur de Francia, nos brilla este agradecimiento «pour la France».

\section{5 octubre 39}

Cuando se viene aproximando la época de los fríos, todo el mundo organiza sus cosas para el frío. Aquí, en nuestra «única ciudad», es otoño y es invierno. Cada uno ha rebuscado en sus maletas - o en sus makutos o en sus cajas francesas- y saca al sol las ropas de abrigo.

En la «avenida de los ingleses» — la gente traduce así los paseantesse ha instalado el Rastro. Tenderetes y puestecillos, vendedores... y mirones. (es curioso observar que casi todos pueden ofrecer ventas y casi ninguno puede ofrecer... dinero para comprar. Después de todo es lo natural. Ni un céntimo queda ya. El tiempo y las «ensaladas» hicieron sus gastos en los bolsillos, pobres de por sí.). 


\section{1 noche. Agonía de la vela que me alumbra}

Ha comenzado a llover, a renovarse la lluvia de ayer y de anteayer y de muchos días. Llueve incansablemente. Potro trotón la lluvia.

Los islotes se hacen islitas. Montículos aislados, donde bulle el barro y el malhumor. En los restos sociales que son los grupos de refugiados es un estrato vivo el malhumor. Para mí, como consecuencia de verdosa esperanza, queda el ánimo. De tal manera, que con el barro el optimismo son elementos indispensables para una filosofía «local». Tanto, que creo que los filósofos áticos olvidaron de incluirlos en sus bases filosóficas. Sí, aquellos célebres cuatro elementos: agua, viento, fuego, tierra.

La filosofía peculiar de Gurs — de este campo, no del pueblo, que sigue sin conocerse a pesar de su proximidad - añade hondura conceptual a todo. Y el barro - este barro que nos inunda, que nos cerca con su fuerza atosigante- y el optimismo - este optimismo nuestro que debe salirnos por necesidad- son ya fortísimos elementos. Sí, vida y realidad. (Si no, que lo digan los zapatos de suelas rotas... y las cartas al seré).

\section{7 octubre}

Las cartas - y sobre todo los sobres- son algo así como las agujas. Pinchan. Y clavan. Y se clavan.

Una Carta tiene sabor de esperanza y de certitud. Esperanza, al esperarla impaciente; certitud, al recibirla, leyéndola.

Estos días he tenido carta de casa. Escrita por Tere, mi única hermana y queridísima, como el gran querido, mi hermano José Luis. Carta donde contestan a una mía del 5-10-39. Planteaba los dos caminos: a) visitar España y b) enrolarse alegremente en la «legión».

El amor materno y familiar es el amor. No hay duda. Pensadlo todo lo que queráis. Y la conclusión rebasa lo científico y se queda ante la gran verdad: te quiere tu familia. Así, lo elemental. Mis padres y hermanos adivinan toda la gran pena que aguantamos estoicamente,

Y por ello, lo saben... y esperanza a poder abrazarnos. ¿Cuándo? Ah, ellos, como yo, esperan. 


\section{3 de la tarde}

Estoy en la oficina, como desde hace 5 meses. Cadencia tonta de tiempo sin dirección. Aquí, anclado ante fichas y ante esperanzas de salir como trabajador.

Estas cartas que acaban de llegarme, me animan formidablemente.

Son de la familia Priat, me quieren y les quiero. Creo que la amistad nos es profunda por sencilla y espontánea. Como la verdadera amistad. Línea horizontal, y con todos los puntos seguidos.

En la psicología novelesca se admite que querer es residir en un ser - $\mathrm{O}$ en una cosa - semejante - o complementario- en sentimientos. Y acaso en sensibilidad. Pero esto es lo más difícil. Por eso mi gran suerte. Con los Priat congeniamos ampliamente. Sin proximidad continua, nuestra afección está integrada de recuerdos gratos y de correspondencia íntima y sentida. Ellos, después de casa, son el corazón cariñoso de la familia.

\section{1 noviembre 39}

Apenas abierta la mañana, sin dar tiempo a la comodidad de «resistir» un poco más en la cama -isarcasmo cierto! cama mi montón de paja y mantas en el suelo- marcho a lavarme. El agua, fría, helada como la fecha que hoy es moda universal.

En los múltiples puntos de la tierra geográfica y humana, hoy es la Fiesta de todos los Santos. ¿Fiesta? Sí, un nombre más que añadir a la etimología equivocada. A la cosa ingenua de «entretenerse».

Llaman fiesta a las horas de alegría. Hoy, en cambio, es la tristeza. La tristeza hecha norma colectiva. «Standard», como los helados «Ilsa» que vendían en Madrid.

Para mí, el luto y esta tontería de recordar a un mismo tiempo todos los muertos — nada menos que todos los muertos- es una estúpida desatención. ¿A qué? Al honor y la exacta preocupación sentimental que merecen los que ya no viven.

En los cementerios, el 1. ${ }^{\circ}$ de noviembre, todos los años, en plan metódico, los familiares de los fallecidos visten de etiqueta a sus tumbas. 
Donde exhiben flores compradas a última hora. O guardadas del año anterior. Los muertos saludan desde su habitación acalorada. Allí resbalan las palabras...y los pisotones... y las confidencias que hacen sonreír a los que duermen despiertos.

Hoy, cerca del «bureau», se escuchan los golpes y tañidos de campanas próximas. Tocan tristemente. Penas. Muertos. Huecos en familias. Dolor. Ausencia.

1. ${ }^{\circ}$ Noche. Silencio. Sin trajes de gala, silencio.

Nieve en la cadena de los Pirineos.

Me están mirando los montes nevados. Los Pirineos. Están ahí, cerquísima. Y su gorro de barba blanca me incita a mirarlos. Acaso por inercia de contemplar paisajes. Quizás también por mi impulso subconsciente hacia la poesía y la estética.

Bueno, lo que sea. El caso es que me llaman estos montes plomizos y verdosos. Me atraen calladamente. Lentamente. Que es como más se atrae.

Y recuerdo y sueño y pienso. Claro es que vivo y no necesito dudas cartesianas. Sé que vivo, y por eso pienso y sueño y recuerdo.

Los montes y picos pirenaicos son algo así como la invitación a la nostalgia. Pero desgraciados de aquellos que se consumen nostálgicamente. Jamás llegarán a ser nada de propio gastados. Su afán de morriña y experiencia memorial les ha vencido. Y con el tiempo, caen derrotados.

En cambio la naturaleza, aún cambiando la altura de sus Pirineos, persiste estéticamente y como fuente y como espejo y como línea.

\section{3 noviembre}

Se hablaba esta mañana sobre los vendedores de botijos. Sobre su pintoresquismo. Y sobre todo, incomprendiendo su estilo decidido de lanzarse por regiones lejanas a vender. Sí, a vender. Con 20 botijos y un borrico de panza peluda y suave. No sé si J. Ramón los estudió en su 
alma aventurera. Los gitanos, con sus botijos rojos y relucientes. Pero él vio la nostalgia sentimental de los borriquillos.

Yo veo grandeza y despreocupación en su marcha algo nómada para "vender botijos de la Alcarria» o "gallos rojizos de Andalusía» con su_s final y guasona: Con sus tenderetes portátiles, casa y humor a cuestas, al Norte, a Madrid, a Bilbao, al extranjero.

$\mathrm{Y}$ es que resalta su independencia frente a la vida. Son, acaso, el único puerto donde existe «zona franca particular». De buques, los burros. De mercancías, los botijos. Y sobre el mar y las olas que son las provincias y las carreteras un ansia viajera y curiosa.

\section{7 noviembre}

¿Habéis sentido alguna vez clavarse el recuerdo? Como una daga finísima me desgarra cosas inolvidables y suspendidas constantemente en mi memoria.

Apenas cúbrense de musgo y de laurel los días de aquel 7 noviembre 1936 en Madrid. Son tan altos los gestos de estoica heroicidad, de preparación a la muerte defendiendo el honor, que hacer frases es ridículo. Cosa pequeña y entumecida.

La carne necesita cuidados. Y el espíritu exige algo más. Cantos, verdades, una amplia donación de la sensibilidad. Para mí, este aniversario en su $4 .^{\circ}$ año — como los estudios, avanzando- demuestra una intensidad de aquella fecha. Y sin halagos ni apellidos falsos, les ofrezco esa sensibilidad sentimental máxima.

Original es esta primavera naciendo aquí, Sur de Francia. Tonos en bullicio de elogios y de nostalgia. Y, por todo, corona viva de emoción.

\section{4 de la tarde. Sol de verano. Y calor}

Llevo varias jornadas — unas tres semanas ya- escribiendo los poemas de «la presencia alejada». Sí, el amor íntegro y novel, de niño y de enamorado. Juego de corazones, distantes... y cerquísima. 
Hay un arco lanzado sobre las esperanzas de querer. Y un «te quiero» atraviesa el Atlántico uniendo dos ilusiones: Águeda y yo.

El rebosar quietud de amor es desesperante. Mecha que aviva lo que ya arde, y con gran intensidad. Este cariño mutuo volando sobre las horas eternas y místicas del Campo. Y sobre la angustia que aflige a Águeda, forzadamente lejos.

Todo embadurna los huecos que se estremecen. En mi sangre su recuerdo salta en cada glóbulo. Y esta extraña primavera - rara flor de Noviembre- dándonos besos amarillos de un gran sol blanco. Como una profesión de tiempo bello y en gama de matices. Rosas y violetas y azules y verdes y blancos y rojos. Sí, una inauguración «en reprime de gran gala» de primavera.

\section{1 noviembre}

Las fechas suelen clavarse con fuerza. A veces, terriblemente evocadora. Y nostálgica. Despertando sensaciones y estampas y remembranzas.

Para nosotros, este hacer luz con grasa, este acuciar semanal de lavar y coser la ropa, haciéndonos más integralmente alejados de nuestra civilización — porque nos alejan- es algo así como la liquidación de una gramática falsa. Donde todo tiene sentido de futuro. Y donde el pasado es fuente. Y cuadros con figuras que dominan este presente.

El 11 noviembre ¡1918! Recorrían las calles los cortejos. La alegría saltaba las lindes de lo normal. Un coro de familias desoladas veía con envidia la felicidad ajena.

Sí, una persistencia de dolor. Me miro, introspectivamente, y comparo «esta ciudad» con las villas alegres del 11-11-18. Alegría, sí. Y tristeza también. 


\section{9 noviembre. Es casi negra la noche. 21:15 horas}

Después de haber pasado la tarde con MENA —el buen amigo y camarada Jesús J. MENA Mateos, escritor y pintor - se afirman las ideas que me bullen. Agitadamente, descansando hasta serenarse. Hasta hacerse estratos, cimientos conceptuales.

Sé que tres normas basifican la vida: 1) el amor; 2) la familia; 3) la amistad. Sin estas líneas que fertilizan la realidad, es falsa la existencia.

¿Caminar con los ojos vendados dentro del barro de nuestros islotes? Es abrir las pupilas hasta hacernos daño el reflejo de la lluvia en los charcos. Hasta el barro, hincándose en los tobillos con su adusta humedad.

Si alguna vez se exigía estudiar lo real, es ahora cuando experimento su necesaria lección. Acaso la sangre y la carne - como ya buscan algunos filósofos vitalistas- sean la dirección de los sentimientos. Continuidad. Explicación. Trabajo e influencia en lo temperamental.

Sé también que no puede romperse el placer el poeta. «Rêves», clavando la buena palabra francesa. Sí, soñar. Pero sueño basado en esta realidad fea y normal de todos los días.

Sé también que la vida monótona de los campos de concentración aviva el cinismo y la hipocresía. Porque nos barre cruelmente el malhumor y - a veces- la desesperación.

(Algún día analizaré las causas de todo esto. No es más bella la historia por callarla. Ni tampoco más pulida por adornos y espesa. Cuando los hombres débiles de espíritu nos gritan con su idiotez, se exalta y exacerba la tranquila monotonía. Son flojos culturalmente. Hombres sin escalera, faltos de escalones quieren llegar al acierto. A la verdad. Y al fondo.)

Por eso creo que hoy es bullicio. Ya lo escribiré. 


\section{4 noviembre 1939}

Desde hace algunos días este sur de Francia tiene un estilo de frío. Mucho frío.

En la cama doy vueltas y más vueltas y no consigo liquidar absolutamente esta helada temperatura. Hasta ahora dormía desnudo, «vigilando mi higiene». Pero esta noche, a eso de las 3 de la madrugada, he tenido que ponerme la camisa «sueca». Tan larga y con algo de felpa, que hace de pijama.

Los psicólogos ingleses se preocupan enormemente del problema de la risa. Análisis complejo de lo usual. Sí, problema. Pero no agudizan en el frío. Donde es índice las extremidades inferiores. Con el frío, los pies están helados y parece que me arden. Como si estuvieran en hoguera. Sambenitos de las noches gursanas. Como si las llamas, solo las puntas de las llamas acariciasen las yemas de los dedos. Clavándose, como alfileres. Frío. Y arden los pies.

Aproximadamente, en esta fecha del año 1937, salí de casa, de Madrid, para ir a Valencia. A la E.P.G. ¿Días hermosos? No, inolvidables. Por eso se me hunden en el corazón las últimas palabras —salidas de un hondo sufrimiento maternal- de mamá. «Van pasando meses y años desde el último día que estuviste cerca de nosotros. Yo los paso resignadamente por ir en ello tu felicidad».

Sí, sublimación del dolor.

Pero mis padres y mis hermanos, serán felices. Yo lo prometo. Lo haré.

Merecen días felices. Angustia, continua zozobra, no es receta normal. Ellos tendrán felicidad. Y lo haré.

\section{0 diciembre 1939}

No puedo escribir. Es algo tan enorme comparado conmigo mismo. El más grande cambio de mi vida. ¡Dejo el campo de concentración! El contrato de trabajo, en mi bolsillo. Son las 7’30 de la mañana. Y el aviso que me llega: el Sr.Priat nos espera. 
La realidad es, a veces, sumamente fuerte. Su haz de alegría choca en el depósito amargo que dejan los recuerdos. Y los sinsabores. Y las injusticias.

"Atrás», «allá», quedan buenos amigos. Camaradas. Y un hábito de nerviosismo nos recubre. Tanto, que ni Pedro ni yo acertamos con nuestra personalidad. Personalidad que, habitualmente, tenemos. Más o menos escondida por una actualidad desesperante.

Han sido más de 10 meses - anoche los cumplimos- de vida en "única ciudad». Lecciones de dolor. Y de firmeza de espíritu. Optimismo. Ansias. Siempre verde la esperanza. Voilá!, hoy llega la fecha.

Montamos en autobús hasta Oloron. Luego, allí, la estación. El tren... y un billete hasta Pau. Un taxi nos lleva al "cottage» (en el camino reflexiono. Hace unas horas - muy pocas- era el refugiado n. ${ }^{\circ}$ tantos. Ahora, ya estoy en camino de ser ciudadano. Libertad. Oh, tantas cosas dibujadas en esta usada palabra). Ya llegamos al cottage. La familia íntegra nos recibe. Mme.Priat - mi «maman française»—, Suzon, la tantine, Georges (que dormía), en fin, hasta el perro saluda alegremente. Estos besos de familia me recuerdan la mía. Sí, con estos kilómetros de separación, añoro más mi casa.

Pero, ¡qué ternura nos derrocha la familia Priat! Su bondad y corazón sincero. Ya pronto, por ellos, tendremos trabajo. Un contrato. Y, por lo tanto, el título de libres se albergará en nosotros.

Este domingo es sumamente histórico. Charlamos sin cesar. ¡Teníamos tantas cosas que decirnos! Es el amor familiar, dulce salvia sentimental.

\section{1 enero 1940}

Es la clásica fecha. Y no quiero dejarla pasar sin unas líneas. Saludo. Despedida.

Los días que adquieren categoría de festivos son ya un clasicón que suena con su hora marcada. Esta noche - año viejo y año nuevo- los hogares recuerdan todo. $\mathrm{Y}$ es justo que yo, constantemente besado por la fibra sensible familiar, escriba estas notas. 
Deseo que 1940 sea la paz y la felicidad. Baluarte donde aposentar la dicha que hoy falta.

Pedro y José, conmigo, cenamos juntos. (había olvidado el acontecimiento. Desde el 14-12-1939 estamos en Mont-Disse, B.P. ¡Como agricultores! En realidad, no merece la pena. Es casi ridículo).

Es preferible que sigamos soñando en el futuro de triunfo que nos espera. Por eso, el trío, en sencilla y amical reunión de consejo de ministros, come las uvas. 12 golpes del péndulo. 12 uvas, 12 momentos con viva ingenuidad. Costumbre. Tradición. 12 campanadas. En el recuerdo entra el año. Y se «va» otro.

\section{9:30 h. 4 o 5 de enero}

Se ha posado el dolor. Con su justificación tonta, las cartas han traído la noticia. Mena, el buen MENA, se marchó. A España. A la patria. Amargamente dolido, él se fue. Lo sé. Lo «intuyo». Veo su corazón noble cantarlo. Su carta es un himno a su dolor. Que es el mío. Que es el nuestro. Presencia y ausencia. Pasado y mañana.

Me ha entristecido esta noticia. No la esperaba, Sí que debemos reaccionar positivamente. Pero no puedo esquivar esta noticia. Me golpea. Me atosiga. Y, a pesar de haber hecho cuanto pude por ayudarle, un grito humano me muerde. Como culpa, como error.

¿Dónde estará a estas horas? ¿Qué hará? Siento ganas de gritar. Para explanar mi alma contra lo injusto. Contra la desgracia. Contra le tragedia de los «habitantes de única ciudad». Que no merecen. Que no merecemos. Que sufren. Que sufrimos.

Mena, mi buen amigo Mena, Tú sabes que nuestro lazo amistoso es profundo. Acéptalo. ¡No lo pierdas nunca!

\section{6 enero}

Es francamente grotesca la vida aquí. Sin afanes propios de la civilización. Pobre. Pobre. 
Suele decir el «patrón» que «le temps c'est de l'argent». Sí, el tiempo es oro. Pero el tiempo sin reloj es un crimen. Un abuso de los límites. Hace falta dar limitación al tiempo. Hacerlo «medible». Y con medidas, el tiempo es dimensión al propio tiempo que es oro.

Estoy seguro que Einstein demostró -al menos, en sí mismo, dentro- que medir la distancia temporal es necesario. Y casi diría que conveniente para los asuntos. Para los negocios.

Pero esta «roñosa» concepción campesina de la vida no entiende eso. Solo ve - lo «quiere» ver- las horas y las horas y las horas. Trabajar sin descanso. Siempre.

¿Y para qué? ¡Qué pobreza más descarnada!¡Qué asco! Tenemos que enseñarles. Que miden al tiempo con «gafas y con metro y con reloj». Sí, con límites.

\section{1:35 h. 8 enero. Solo en mi habitación}

¿No conocéis «mi» habitación? Es pequeña. Callada como un remanso de agua. Apacible. Bastante blanca. Con las paredes limpias. Una cama. Una mesa no muy amplia. Unos libros. Cuartillas. El tintero de la Waterman, el diccionario de francés y de inglés, el cepillo y pasta de dientes... y un porta-retratos.

Aquí yo. Con la lámpara que me alumbra. Y la ventanita, sobre mi cabeza. De día entra el aire. Y mañana, a las 6 de la mañana, me «ofrecerá» el negro ahumado de la noche haciéndose día.

Han venido tres chavalillas. ¿Y qué? Necesito inflar estas horas con algo agradable. En esta habitacioncita. Me encuentro a gusto. Cabalgan las ideas. Me siento el Jacinto de siempre. Bullicio al futuro. Optimismo. A pesar de que, ahora, los bueyes exhalan «su» realidad. Sí, aquí al lado, junto a la puerta.

Pero, bueno, poetizar se construye de realidades. Y ya que habéis visto mi sala, los poemas son vuestros. 


\section{1:45. Niebla, lluvia. 27-1-40. Sábado}

Estoy completamente asqueado de esta concepción absurda de la vida. Absurda, mil veces absurda.

Además, me parece ridículo que yo esté aquí. Yo, con mis estudios a cuestas, con mis escritos en el vibrar de cada respiración. Y sí, soy yo, haciendo de «ouvrier agricole». Según lo dice el contrato.

Bueno, feliz —o desgraciadamente- este suplicio acabará el 9 de marzo. Y, junto con Pedro, iremos «adonde sea». Todo, menos esta vida grotesca.

He estado pompando casi todo el día. Un barril de 2100 litros de vino. Otro de 700. Otro de 1200. Y luego, para remate, otro tonel de 2100 litros.

¿Una delicia? Sí, una «pequeña» delicia. Y no es lo peor del trabajo. Lo malo es que me encuentro siempre mal, a disgusto. No conocen nada más que la tierra. No hablarles nada de la civilización. Oh, —ellos dicen- «los inventos y todo eso lo hacen gentes que no tienen nada que hacer».

¿Comprendéis ahora? Pues imaginad lo horrible de mi tragedia. Analizo más y más. Y sólo veo negrura absurda en esta vida. ¡En fin, pobres espíritus!

En cambio, recojo notas. Como ésta. Sé hoy que Lorca tenía razón en sus «Bodas de sangre».

Veo aquí, en honda sencillez, principios enormes de moral y de decadencia espiritual.

En la campiña de este Mont-Disse - y creo que en todo el mundo es igual- se vive con diferencias sexuales. Sí, los hombres son los hombres. Las mujeres son las mujeres.

Así, secamente. Sin adornos. El hombre, es más fuerte, más macho, más potente. Y la mujer, es la mujer. ¡Cómo un pozo la convicción sexual!

Al referirse a los esposos, dicen «tu hombre», o «mi hombre». Cuando hablan del trabajo exclaman: «ah, es una tarea para las muje- 
res». Y al acercarse la hora de la comida, las mujeres dicen: «ihála, que van a venir los hombres!».

Encierro de léxico. Y salida de estilo irracional.

\section{Mismo día 27-1-1940}

No puedo comprender cómo nos han abandonado los sutiles camaradas del mundo. Claro que no son ellos; son las circunstancias. Agarrotan los partidos para impedir que el pueblo conozca la verdad. Matan lo popular.

Hoy, con síntesis dolorosa, compruebo que es un año amargo el perdido bajo «nubes molierescas». Me cuesta trabajo admitirlo. Más la creencia es justa. Lo vive mi carne y mi pensamiento. Lo rezuma mi esqueleto y mi peso. Me han tenido acosado como un chacal, dentro de barrios chiquitines, con bayonetas y alambradas.

¿Es que merecemos esto? ¿Por qué no se abren las puertas de las casas para nosotros? Han ofrecido contratos: sí, que los intelectuales y los estudiantes y los artistas trabajen como peones en la agricultura. O sea, que desarrollen su fuerza «muscular». Como las bestias. Ejercicio del músculo, intentando anquilosar la inteligencia.

Pienso dolidamente esta noche. Quiero soñar. Lo necesito. Que el triunfo nos besará. Optimismo. Es una necesidad como otra cualquiera de primer orden.

\section{7-febrero-1940. 10:45 h de la mañana}

Estoy en la cama. Medio malucho. Un poco de gripe. Y tengo ganas de escribir.

He observado que, durante mis enfermedades - cortas o largas- experimento como acuciante ímpetu el deseo de escribir. Y de reflexiones.

Me imagino a Jeannette - la pequeñilla de la casa, rubia y con sabor de campesina idiotizada - cuando cantaba la otra tarde. Sí. Su edad le 
empuja cantando. Como anhelo para arrojar el lastre de su alegría. De su insignificancia, mejor dicho.

Están llenándose las horas de un tiempo con sol. Y en el tiempo de nuestra juventud un sol de triunfo que va a venir muy pronto. Con fuerza. Con seguridad.

Porque la «entente Pedro-Jacinto» es algo formidable. Comprensión de sentimientos. De fines humanos. De trabajo. De voluntad. De... — ¿porqué no decirlo? - de inteligencia también. Los dos ofrecemos un conjunto de juventud marchando hacia el éxito y la lucha.

Hay una línea de entusiasmos, mecidos en años estudiantiles. Fraguados en los 3 años de guerra española. Y en los 10 meses de campo de concentración. Y en estos 3 meses como campesinos. Ansias jóvenes, en brío de verdad y anhelo.

Sé, con esta pequeña estancia en la cama, que André Maurois está equivocado. La juventud de hoy es alegre... y con sed de obediencia, nos dice. ¿Dónde buscó tal concepto? Que hable con nuestra sangre. Que remire en los archivos clarísimos de los estudiantes revolucionarios.

Hay una pasión de gozo en nuestra «entente». Porque tenemos confianza en nosotros mismos. Y yo, en mi familia. Y en Águeda, ya hoy libremente en tierra mexicana.

Intento releer las cartas aguedinas. Las tengo numeradas. En un paquetito, bien puestas y con una delgada cinta azul. No es simplismo. Es que la quiero. Y con mi fiebre, tengo miedo de que ya no me desee. Pienso que los kms. y el tiempo con lagunas mata $-\mathrm{o}$ amortigua- muchas cosas. Y, acaso, también el amor.

\section{2 marzo, sábado, en mi habitación}

No debo dejar pasar esta fecha sin una nota lacónica. Sí, tengo motivos que harán después vibrar el recuerdo.

He sido - nada menos- que vaquero esta tarde. Guardando los bueyes - ocho- no vayáis a creer. No vaquero de nubes ni de montes ni de 
paisajes. Pastor de ideas mías, que llevo a pastar por la psicología de la sociedad y del anhelo.

Nunca habría podido imaginar «esto». Pero es así. Y, como dice Tere —mi queridísima hermana- hay que aceptar las cosas... con amor y buena voluntad.

Francamente, creo que debe ser así. Pero no puedo. Me rebelo $-\mathrm{y}$ como no puedo resolver nada, me hago daño en mí mismo, dentro, moralmente- contra toda esta serie de injusticias. De sinsabores. De amarguras no merecidas. De «premios» a nuestra honradez.

Aunque sé, nada más que antes, que no sólo es derecho a la felicidad, sino también deber a la dicha. Sí, tengo el deber de encontrar —en lucha, claro- la dicha.

\section{9 marzo. 6:40 de la tarde}

Los días, en su marcha normal, colectiva, general, suelen ser mareados con acontecimientos personales. Que valoran las fechas. Sí, dando un sentido de potencia en la vida individual.

Desde el 9 actual, hemos dejado la vida de campesinos. Se dijo, "après, Mont-Oisse». Y hoy, después de un periodo de incertidumbre, tenemos un nuevo contrato. Y, por tanto, un nuevo empleo. ¿Cuál? Es ridículo confesarlo. Pero no, no es idiota. Es halagador, porque supone nuestra fortaleza de ánimo. Somos... carboneros. En pleno bosque. Pueblecito: Montant-Bétharram, en los Bajos Pirineos. Cerca está Lourdes.

El bosque, con su ruido de silencios. Pisadas blandas. Nubes sobre las canciones. Y humo de las carboneras, inundando de blanco sucio una tarde sin sol.

Veo la montaña blanca de Lourdes. Con un tajo enorme en su vertiente oscura. Tajo, cuchillada. Donde circula el funicular. Bocado de motor en el monte.

$\mathrm{Y}$ aquí, en el bosque, los tres mosqueteros, nos morimos de asco. Trabajo sucio, sucio, fatigante, sin renumeración. Tarea casi de salvajes. 
Nos honra nuestra etapa como obreros. Mostramos la excelencia del estudiante con ímpetu renovador. Sí, estampa sin facetas limitadas en cuanto a deseo social.

Por eso, nuestras jornadas en el bosque. La "pila bendita», que la llama otro español. Porque recoge lluvia todos los días. Es una hoya vegetal, con árboles enormes como adorno. Silencio hondo de tan fuerte.

Aquí, en nuestra chavola. Maderas con sacos. Y yo, para recuerdo, he escrito una «poesía carbonífera». Y dos dibujos simbólicos, rememorando próximas visitas.

Además, he descubierto. ¡Sí, gran cosa! El «pájaro-fox». No reíros. Es cierto. Un pájaro que canta un fox. José y Pedro se divierten con el gran descubrimiento. Pero... la música nos trae sensaciones guardadas. Bailes. Tardes con niñas. Aulas. Cines. Palabras y besos. En fin, ¡viva el «pájaro-fox»!

\section{Con luz de carburo. 30 marzo 1940, noche-22 horas}

¿Porqué persisto como carbonero y he persistido como campesino? Hay una profunda razón. Lo que mueve mis ansias actualmente. La que me impulsa aceptar otra tarea más pesad todavía, si ello es necesario.

Quiero resolver mi situación y ayudar a mi familia, coronando este anhelo con mi amor hacia Águeda. La quiero como un chaval enamorado. Tanto, que casi meda miedo anotarlo aquí. Sí, porque me haría daño que ella me olvidase y no me quisiese ya.

Está en México. Libremente, estudia y trabaja. Y en cartas por avión me escribe que me recuerda y me ama. ¿Por qué tengo este temor? De tanto como la sueño. Sí, porque la pienso en todos los momentos.

El 19 actual la escribí por avión. ¡Qué emoción esperando su respuesta! Cuento los días, a ver si llega su voz. Que las guardo en mi corazón. Que ella me tiene, como yo la tengo constantemente. Y añoro ¡qué rabia no hacerlo ahora mismo el reunirme con ella. ¡Allá, juntos, para vivir! 


\section{Domingo, 7 abril, 6 de la mañana}

En Bétharram. Apoyado en el viejo puente. Piedras. Tiempo en domingo. Se detiene un coche. Kodak. La fotografía cantará después, a la lejanía, recuerdos del puente.

Un río corre, azul verde, tranquilamente. Bajo la arcada pétrea —una sola, hiedras colgantes - se ve al ciudadano-pescador. Con abrigo y sombrero, pescando. ¿Ridículo? No. El «toma la vida así». Con caña. Con sombrero. (Acaso trabaja toda la semana, para apreciar el reposo y el cántico del asueto placentero en horas de pesca. Acaso lo idealiza en su trucha).

Bétharram. Carretera Pau-Lourdes. Enfrente, el colegio. Enormes y delgados edificios, que siguen la carretera y el río. Colegio. Cientos de ventanas.

Capillas. Campanas tañendo. Golpes en bronce... y en el vacío. Montes y nubes, con galerías y cristales.

Paisajes o su cinema. Sala auténtica, donde veo la naturaleza. Sin rencor, como cuando estaba en Mont-Oisse, que me cabía daño la primavera en la «campagne».

\section{4:10 de la tarde}

Aquí, un infantil riachuelo paseando con pequeño bullicio. Guijarros, como adorno sencillo.

Y nosotros - con Mme Priat y Susana- en este prado. Por donde marcha la ruta de Lourdes. Hemos hecho la comida al aire libre. Bajo el sol y las horas agradables. Hermoso día. Sosiego familiar. Contento.

Sé que la amistad vale mucho. Estas botellas vacías, estos platos comidos en cariñosa armonía, es formidable. De mesa, una cesta y las rodillas. De sillas, piedras. (Os aseguro que la mía era la más dura. Trapezoide. Me dolía el posterior mucho. Deseo mejor una butaca mullida, donde se reclina el silencio de mi cuerpo y de mi sueño).

También el gozo ofrece la idea en contraste.

Me revolotea una avispa. ¿Presagio? No creo en signos supersticiosos. Aunque experimento en mi dolor la más tremenda de las equivoca- 
ciones. La he sufrido y la sufro. Quieren conocerme «especialmente». Bajo un tamiz de circunstancias personales, a su modo. Interpretación de ellos, también hoja temporal.

Y en línea provisional todo, un juicio que perdura. Pero es mío y ya tiene valor sereno. Aquilatando lo quieto, maduro: sé que soy bueno y me lo demuestro. La opinión de otras personas puede tener interés. Pero lo definitivo -opino como Unamuno- reside en la concepción individual que de uno se tiene. En análisis dentro del «yo». Yo, en mí. Cada uno en sí. Y de ahí depende la vida. El éxito. O el fracaso.

Una claridad de nubes alargadas mece mi pensamiento. Ruido de naturaleza. Vida.

Me molesta la concepción «a la ligera». Sí, esas apreciaciones como caballos sin brida. Y que al caer sobre una persona puede ser peso aplastador. Rompiéndole su honrada personalidad. Le pinchan. Son avispas humanas que clavan su aguijón mordaz.

Lo experimento en seres conocidos a fondo. Había ofrecido mi clara amistad. Que valoro en mucho. Y, hoy, una dolida experiencia explica mi error. Sí, porque creí que en sinceridad no existían uñas sucias.

\section{1 mañana. 13 abril, pleno bosque}

Esta hoya ocre en el bosque. Agujero en la naturaleza con vítores a los árboles y a los riachuelos.

Aquí, las hojas han desaparecido. Primavera en viaje retardado. Todo, la realidad y la vida, está estancado. Buque bien hundido.

La luz. Un color bien gris y profundamente extendido. Un color que, como los gases, rellenan volúmenes espaciales. Y cubren grietas entre las ramas.

Parece que se reduce la altura al techo azul. Menos diferencia entre la tierra y el cielo. Sí, hoy, todo en líquido pizarroso. Como si la atmósfera se invadiese de ventanales idénticos en su gris. Ventanales seguidos, siempre adyacentes. 
En la inmensa mañana, un reposo.

Una pequeña cabaña. Nosotros, los carboneros.

$\mathrm{Y}$ voces que demuestran la existencia

Existencia del reino vegetal. Las plantas. Las hierbas. Los árboles. Las lianas. Los prados.

Existencia del reino animal. Los pájaros. Los hombres. Los pececillos. Las babosas. Los caracoles.

Existencia del reino atmosférico. Las nubes. El aire. La lluvia. Las capas.

La vida, con etiquetas de botica científica.

Una vida tan amplia, archivada.

Profusión de seres vivos y muertos. Anchísima catalogación de maderas, de arbustos, de tiempo.

Sobre el amarillo blanco de las margaritas, vuela una pequeña mariposa violeta.

Yo, en lo alto de este bosquecillo. Donde se consumen las dos horneras. Humo con vetas oscuras. Un proceso de combustión. Que roe la tierra y que nos dará el carbón. Bueno, sin risas. Y el rescoldo. Quizás, troncos sin quemar y cenizas.

Se empapa el aire de esta delgada lluvia. Quebrantando múltiples hormigas negras que horadan su túnel y su trabajo.

\section{6 abril}

En el altar de este mediodía nos luce un desfile de nubes azules, celestes, blancas. Tranquilamente, cabalgan. Como el cochecillo infantil en el parque. Todo lento. Suave.

Bulle el bosque con su marcha agitada de tanta quietud. Esos gritos vegetales que despiden los castaños. Y la letanía tristona de los troncos cortados. Donde se cebó la sierra, haciendo crujir en espasmos de impotencia al árbol. Sí, lloraba. 
Lo vi. Cuando los leñadores, con su tronzador abrazaban estrechamente la circunferencia del roble. La savia cantaba su pena. El aire bebía con aspiraciones resinosas. Junto al compás alegre de los hombres se avivaba la muerte del árbol. Con odio. Con rabia. Su miedo también. Dejándose cortar en la base. Con mansedumbre.

El árbol tiene religión. Cree en la resurrección de la vida. En la reencarnación de la madera.

Si hoy explica su biología de tronco, armas y hojas, mañana será un mueble, o carbón, o una traviesa de ferrocarril. O un mango de hacha, ayudando a matar a sus hermanos árboles.

La vida tiene estas diminutas contrariedades.

Después del pequeño aguacero de la mañana, ha quedado un cielo casi tenso. Puesto a secar. Ropa de nubes y sol. Y surge de la tierra, esta tierra tan ricamente abonada por varios siglos de bosque, un aire sano. Lleno de orgullo. Entero de vida. Tierra con humus natural y guardado. Tierra intacta para la agricultura. Quedamente, como el gato cariñoso del hogar, nos acaricia un perfume de aire puro y forestal. Bosque. Cortándome el cansancio este mediodía airoso y optimista.

Se levanta del bosque un rumor de respiración. De gigante. Quejido espeso y rotundo. Con toda la redondez de una vida fuerte. Bosque. Silbidos silenciosos en las nubes.

\section{7 abril. Siempre en el bosque}

Un día soberbio de luz y sol. El bosque tiene aspecto de fiesta. Más color, más vida, más ruido. Parece que un sonido ronco y puntiagudo subía de los árboles y del monte y de los riachuelos. Joven. Dominante.

Por aquí, pájaros de primavera. Flechazos musicales en el plano azul. Las nubes, con la espalda tostada por el sol, se acuestan sobre otras nubes. Y se alargan. Como colgándose entre sí, atadas.

Leo. "Le chant du monde», de Jean Giono. Admirable libro. Lo encuentro con Miró. Y algo con Lorca: Leo. No sé si alguien ha dicho que 
la lectura es, siempre, un poco la huída. Pero yo lo digo. Y es también marcha hacia el interior. Huída y reconcentrarse. Por eso es bello el leer en soledad. Estar en sí - bien dentro- mientras se evade uno en los pasajes de los libros. La lectura es algo huída sí, pero es una incorporación a ser plenamente uno mismo. Buscándose, como el cuchillo su corte, en la presencia y en la lejanía.

En tanto, el bosque sigue como estampa verde, nueva.

\section{8 abril}

Vamos paseando. Desde el bosque, donde se queda un ambint largo, solo, muy abierto. Y los pasos marcan ruta hacia Montant-Bétharram; más aún, hacia Coarraze.

Hay luz sin medida. Longitudes. Alturas. Un ancho paisaje. Lo que goza de mí en este paseo, no son las piernas. Son mis ojos. Placer para mis retinas.

Gozo de belleza. Línea pura. Limpia. Un cielo y un paisaje recién lavados. Despídese un sabor de tierra bien mojada.

Más adelante, el campo ofrece respiración de plantas. Instalación de vegetales aclarando nuestro olfato. Belleza que brinda la naturaleza a mis ojos.

El tiempo pasa. 5 de la tarde. El sol lucía su aire. En Coarraze. Un hogar. Cocina amplia. Con bruñidos bronces, que son como delicados espejos metálicos. Música. Valses. Que me llevan la cabeza. Valses. Esto es la locura. Estoy loco. Y la realidad sencilla, con encanto auténtico. Desde su jaula, el pájaro que canta al aire juguetón de Strauss. Maravillosa música. Locura. Mi cabeza rueda, gira, sueña. Un movimiento consciente de felicidad. Oh, qué feliz soy en este momento. Un segundo, otro, el vals que enseña calidades de sentimientos. Me grita la cabeza. Me bailan los cabellos. Todo es melodía. Y, yo... de carbonero... Sí, tengo que «rêver». Tengo que soñar. Sé que es la enfermedad, pero no tengo más remedio. Valses, el día limpio de nubes sucias, el canario en su jaula, libre en su voz. 


\section{Domingo 21 abril de 1940}

La noche.

Una luna redonda sonríe tras un visillo de nubes pálidas, avioletadas. Morado de horas tensas, fibrosas.

Medianoche. El ruido del bosque, habla. Sí, voz. Murmullos del bosque que son una conversación.

Los sonidos son claros. No puedo saber si son voces femeninas o masculinas. Ni sé si son voces individuales. Sé que siento la voz en su hablar concreto y delimitado. Como el ajetreo de un bar. Muchas personas que hablan. Que gritan. Y, de tiempo en tiempo, un grito más agudo, más hondo. Resbalando, como el escalpelo.

Más sonidos. Más rumores. Más suena el bordón opaco de esta noche amplia. Noche extensa, alargada. Hace esta noche que golpeen las estrellas intactas. Que las montañas huyan. Y solo queda esta profunda respiración del bosque, bajo un cielo muy azul marino.

Apenas ya, nada. Un silencio que, como manteca espesa y oscura, viene taponando afilados rumores.

Queda, persistente, la noche. Esta noche, con su claridad fuertísima, que parece estela encendida.

Los rumores del bosque se agigantan. Semejan la respiración de una gran ciudad. Que descansa y reposa de su bullicio de vida diaria.

Noche. Media noche. Pasos inciertos. Me paro. Y escucho. Me inundo de gritos y conversaciones inexistentes. Es el habla gutural del bosque. Los síís del riachuelo. Los ritmos potentes en la garganta de los árboles. Noche. Cielo maciza.

\section{0 de la mañana. 26 abril, en el bosque}

Una gran ola gris mueve el bosque. Ola ceniza. Con ademán furioso. Que despide gruesas y redondas gotas de agua. Gotas como granos de uva moscatel. Lluvia.

Yo sé que, ahora, el color verde adquiere sus verdaderas y exactas tonalidades. No matemáticas, sino exactas. Porque vienen del tiempo y de la fuerza de la naturaleza. 
Esta mañana, cuando venía por el prado, vi que el campo estaba aún dormido. Apagado. Eran solamente las siete de la mañana. Quedaba una claridad lenta, tímida. El prado tenía lividez de muerto. Verde nostálgico, sin fuerza. Los ojos de la hierba se lavaban en el rocío temprano. Tiernas gotas en los tallos. Un alborozo de frescura en la tierra negra laborable.

Cuando los pies se hunden, mojadas las botas, en la hierba, hay gran ternura en el saludo de la mañana. Todo en diminuto. Acariciante. En cara de sueño. Con rescoldo de haber dormido a pierna suelta la campiña.

Pero ya vive el bosque. Hora solar potente, luminosa. A lo lejos, se abre la silueta maciza de una alta montaña. Entre las nubes, rasgadas en jirones muy finos, el azul va coloreándose poco a poco. Colores en crista. Dibujos coloreados sobre la tierra y la vida y la montaña.

El musgo se apresura en su abrazo sobre la piedra. Y un riachuelo, delgado, pero repleto por el agua licuada de la nieve, pasea su voz de glú-glú airoso.

En las orillas, entre guijarros agudos y ovalados, florecillas violetas describen su anhelo. Balancearse sobre el riachuelo, subidos los pétalos estrechos.

Y mientras la rosa de la mañana recupera su agitación diaria, el verde del prado es más verde. $\mathrm{Al}$ menos, un verde con vida. Con respiración despierta, de Campo vivo y recién bañado.

Sí, un verde joven, con ímpetu en su color (en la ducha del tiempo, el bosque vibra en larga y sonora insistencia de vida y voz y colores).

\section{0 abril}

Quisiera saber como curan la estupidez los médicos. Esos señores que se doctoran y honoran con los libros de medicina. Yo les admiro. Sé, que con los profesores, es el género humano mejor del mundo. Y deseo:

Que curen a los estúpidos que viven de la ignorancia. 
Que la vida sea de pasada hacia estadios espirituales más bellos. Con felicidad y amor. Sin odio. El odio es una botella de vino viejo. Al destaparla, mucho sabor. Y luego, unos tragos. Se acabó el odio. Moralmente, queda el recuerdo. El odio.

Dejad a los poetas vivir su vida sencilla y sentimental. Conocen más la verdad y las cosas que vosotros. Ellos indagan en su sufrimiento. El poeta está dotado para el dolor. Que es gozo. Por eso, el poeta está dotado para el amor.

Las horas tienen una estación. En primavera, se estimula el reloj con los amaneceres amplios. Y con las tardes extensas. Vivid las horas largas, cálidas.

Cuando los estúpidos cierran los ojos, mostrando pinturas en sus habitaciones íntimas, dejadlas hacer. Os enseñan la cama. El lavabo. El comedor. Sus armarios con vajilla cincelada. (Dejadles. Los cuadros son lo de menos. Gentes idiotas, existentes).

Hay una gran porción de "cuentistas». Están enfermos, y aceptan el cigarro y el peine que ondula su cabellera brillantinizada. Sí, pobres estúpidos. Son manías en su debilidad sentimental.

Pido más favores a los doctores. Deseo:

Que resuciten el amor íntegro. Que las personas se amen como quieran. Que el estado tenga sus relaciones con el matrimonio, sin preocuparse de descendencias. Que son paternales y estatales.

Que dejen dormir a los incautos. Aquellos jóvenes — con sus 22 o 25 años-que no estudian ni piensan. El trabajo les adquiere tonalidades psíquicas. Que coman su tiempo. Después, para ser algo, no tendrán apetito.

\section{$1 .^{\circ}$ mayo 1940}

La leña ha crecido en el bosque. Los hombres negros consumirán las carboneras. Y la leña quedará viviendo, ya quemada, en el bosque. 
Toda la falda de la colina guarda despojos. Solo ramas pequeñas. Solo hiedra. Solo troncos de metro y medio de circunferencia.

La leña creció con las lunas y las estrellas.

La leña muere con el sol y las nubes diurnas. Tenía que ser así, sin ser fatalista, fatalmente. Porque la tierra forestal es cobijo. De nacimiento y muerte. Cuna y tumba. Los carboneros consumirán las carboneras. No importa. La ceniza brillará como alto monumento. Flor escuálida, donde las estaciones colocarán su banda de árboles quemados.

Creció la leña. Persistirá el rescoldo y la ceniza. Bosque. Leña. Carbón. Cuna y tumba (en medio de la poesía de la floresta, la estampa cruel que me coloca allí. Yo, aún, como carbonero).

\section{2 mayo}

El viento silba como un perro. Nos ladra. Nos silba. Quiere asustarnos. Quiere mordernos.

Y analizo el dibujo de la voluntad. Adueñándose de uno mismo. Encierro en sí de tanta salida.

Yo, moralmente, a fuerza de ser noble conmigo mismo, caigo en puntos seguidos. Sin interrupción. Derecho. Por mí y los otros. Línea recta en mi nobleza.

Si quieres un vicio, no elijas nunca el de la ingratitud. Ni el de ser desleal contra ti mismo.

Como balanza en la vida, que los hombres sigan un camino justo. Nada para los demás que no lo ames tú. No ya para ti, sino que no lo quieras por lo que ello es. O representa. O significó. Las fases de tiempo tienen cotización. Sobre todo, en el terreno del corazón. Donde hay buena tierra para cosechas. De recuerdos. De remordimientos. De gozos. De penas. De esperanzas. De inquietudes. De sentimientos. La psicosis del mundo tiende a una estabilización: igualarse en cuanto a apáticos y más vacíos de sensibilidad y educación. 


\section{4 mayo}

El fuego saltaba en sus mejillas. Tostándolas. Al color del bronce viejo.

Y más allá, al fondo de la sala ancha, un reloj dejaba sus horas en libertad. Todo quedaba en la oscuridad esponjosa del atardecer. Sobre los cristales, aún un rescoldo de día entero.

Pronto, la noche sería un hecho. Como siempre, vendría de un gran golpe. El día, muerto. Y la noche, con su amplísima sonrisa viva.

Los hombres aquellos daban un tono monótono a la conversación. Voces opacas. Mientras tanto, Luisja estaba ajeno a toda esta pronunciación vulgar. Temas y sonidos de vejez prematuro. Jóvenes sin afán de serlo. El, animoso siempre. Sentado en la silla preferida. La silla de mimbre, con respaldo silencioso, acogedor. En aquellas horas medio oscuras, Luisja no escuchaba el ruido de las conversaciones. Hablaban a su lado. Pero él no escuchaba. Sueño de ilusiones, esperanzas, lucha, por venir, se clavaban como cinceles en su vida.

Y un gran agitar de voces dentro de él. Su propia inquietud diaria. Su normalidad espiritual en acción. Línea en disparo recto, fuerte. Todo su cuerpo era centro emisor y receptor. Resonancia de su misma palabra. Abrazo de su mismo pensamiento. Todo hablaba en él, para él. Con loca y reposada insistencia. El corazón, el pulso, las venas, los pulmones, el cerebro, las piernas y los brazos, la respiración, el bullicio de los glóbulos rojos y blancos. Toda su materia vivía para su habla íntima.

La tarde, en camino hacia el azul marino. Bien pronto, ya comenzaba a verse un empuje macizo, la noche estaría allí, tapando ciudad y hombres y cosas.

Luisja, completamente solo, en sí. Ensimismado con su gran charla. Mientras, al lado, las voces seguían gritando.

(Y es así la vida. Luisja, es muy conocido mío. Y los que hablan, cerca, también. Es la gran decepción de mi existencia entre amigos y conocidos.) 


\section{5 mayo, domingo}

5 de la tarde. Sentado en la terraza del «café continental». Pau. La alegría y la tarde dominguera. Con Planella bebiendo «demis». Cerveza. Desfilan caras bien pintadas. Vida. Autos. Chavalas imponentes. Y el bueno de Planella me cuenta su «aventura con las gafas románticas».

Es terrible en su humor. Y, encima, quiere pasar por tímido. Realmente, lo es. Con algo de miedo. No sé. Acaso le analice. Título del ensayo: «Enrique o la indiferencia».

Está lleno, repleto de apatía. Es indiferente hasta consigo mismo. Siente que la casa se le cae encima. Y me lo confiesa. No hace nada por impedirlo. Se resigna. Sin serlo, resbala en su indiferencia tímida y apática, un fatalismo desorientado, sin método.

Ceo que, con el escepticismo, se persiste en la timidez personal. No gana puntos para mejoría. Planella se equivoca. Creo, que con el optimismo se reacciona en la timidez personal. No en contra de ella, porque es congénita y adquirida. E incluso desarrollada. Más o menos conscientemente.

El poeta $-\mathrm{y}$ en término integral, el artista- no puede dedicarse a crear y a explicar lo que ha creado. No tiene tiempo para esa ingenuidad.

Además, no creo que pueda hacerlo siempre.

No importunarle entonces. dele.

¿Para qué y por qué le exigió explicaciones de su obra? Comprén-

Aprended a sentir sin orgullo.

Interpretar al poeta es una gran lección sabida.

Estudiaros - y estudiále- para esta gran lección. Que es para vosotros, uno a uno.

A veces, no se encuentran ni dos interpretaciones iguales de la fibra creadora poética. 
Y debe ser así.

El hombre es hombre en sí, y no hay dos iguales.

No importunar al poeta cuando no le entendéis.

Debe dejársele suelto en su valle de sentimientos. Herida, su sensibilidad, crece. Y desarrolla exteriormente su pensamiento.

Cuando se realiza no se razona con la fría lógica del estado normal. "L'intelligence — a écrit Bergson, dans "l'évolution créatrice”, pag.179_ est caractérisée par une incompréhension naturelle de la vie». Esto confirmaba mi tesis. Se realiza en estilo distinto del normal. Se vive en alza del termómetro sensible, moral y físico.

Se trabaja artísticamente en un instante - aun cuando sea obra de años- y para un instante. Que se revivirá en todos aquellos que leen, gozan o sienten la obra hecha, "aprehendidos de aquella misma fiebre», de «aquel mismo minuto».

Criticar en sentido negativo es absurdo. Por eso fallecen los que quieren dañar la crítica. Y persiste siempre el concepto vital crítico.

\section{Gurs, 28 noviembre 1939}

( Notas con fiebre». Son ensayos. Y los traslado a este cuaderno, hoy, 13 mayo 1940. Solo en la habitación).

\section{1 mayo}

La mañana. Horas con acuciar violento. Casi nervioso. Se viene estrepitosamente un riachuelo. Aguas verdosas. En verde oscuro. Aguas rebeldes, con atención a sí mismas.

Concentrado en la soledad de gritos y cantos de pájaros. Aquí, en medio de las 10 de la mañana, reflexiones en íntima voz. Sé que la opinión interna desvela muchas cosas. Porque es unidad dentro de la mul- 
tiforme línea de los pensamientos. Y de los hechos. Apartada de la diaria muchedumbre.

Ahora, cuando este sol delgado acude a besarme, me recreo dulcemente. En laxitud perezosa.

Pasan cantando pájaros. Y se quedan alegres. Sobre verdes y jóvenes ramas. Algarada de sonidos. Orquesta sin director apático. Extasío en el bosque.

Los meses ofrecen su tiempo ordenado. Sistemático almanaque, con sus semanas y sus días y sus horas.

El riachuelo mueve con fuerza su estrecho cauce. Nubes, diluidas, esponjadas. En tono quieto, Emilio me cuenta sus andanzas.

Ya lo conocéis. Es un buen hombre. Ojillos entornados, en la penumbra de su frente con rayas. Ha sufrido mucho. La vida le enseñó el lado negro. Superficie de penas. Relieve de dolores y recuerdos agrios. Sí, el vinagre acelera. Áspera vida. Nada de normalidades. Ni un minuto en vida color de rosa.

Emilio es cojo. Estuvo en la guerra española. Fue soldado. En historias sencillas, limpias de puro ingenuas, narra su época de niño. Se ríe. Una barba de varias jornadas le negrea la cara. Destaca el trozo aplastado de su pequeña nariz chata. Se ríe Emilio. Se ríe al compás de sus cejas y pestañas.

Árboles crecidos. Lianas abrazando estrechamente los troncos. En verano, abrazo fresco. En invierno, abrazo cálido.

De abajo sube un vaho de insípidos gritos. En realidad, chillidos. Gritos humanos. Pero en escala descendente. Camino de la bestialidad. Sí, gritos en degeneración de la especie humana.

Por todo, amplia exaltación de la naturaleza.

Una dominante cadencia de valores vivos, fuertes.

Este trigo, crecido en pocos días. Alto, erguido. Con audacia de niño precoz. Prado impetuoso.

¿Quién me dice a mí que este trigo no es un eco, un silbido de felicidad? Acaso sea un temor de poseerla. De ser pura felicidad. En sencillez de campo. Campiña. Alegría del trigo crecido y besado por lluvia fina. 
Su paso de hierba nos viene la primavera tardía. Jugosa, esperada primavera. Que trae un pasmoso dominio de su deber contento.

$\mathrm{Y}$ en este recodo del bosque, yo. Bien acompañado en mi soledad. Compañía de mi mismo. Me hablan los pensamientos. He sufrido la decepción más grande que místicamente puede esperarse de la amistad. No es fácil imaginar mi error. Yo di valor a la personalidad noble. Libremente conocida. Libremente hoy en fuga.

El airecillo despide las gotas que quedaban abrazadas. Desde esta mañana. De cuando la lluvia.

A pesar de las canciones silvestres de la mañana, una vuelta a los pensamientos. Al mañana me parece estar sintiendo la vida de «única ciudad». Con sus valores atormentados. Pero con su seguridad bien esperanzada. En airón los ímpetus de confianza.

Hay que tener confianza en uno mismo. Yo la tengo en mí. Debo tenerla. Es un orgullo sin orgullo pueril. Es un deber. Debe serlo. Para que las cumbres sean subidas.

Demasiadas trabas colocan a mi vida. Pero soy como el buen caballo de vallas. Ganaré el Derby de la vida. Tengo un gran jinete en mi corazón sereno y optimista.

Es demasiado feo el anonadarse. Nada de fracasados. Para eso, la muerte. La desesperación es lógica en casa de aquel que sufre. Pero es admisible en tanto que es parada. Sí, simple albergue donde se desespera. Y donde se emprende audacia en la más grande provisión de seguir adelante. ¿Hablan los almanaques? Sí, nos hablarán bien claro.

\section{6 mayo, domingo. Sol y nubes}

Me voy paseando solo. Una carretera limpia. Límite de Altos y Bajos Pirineos. Las «célèbres grottes de Bétharram». Me acodo en el puente de madera. Bajo a las rocas. Sentado en arena gris. Tocando el agua. Baile de olas rabiosas. Empuje de jóvenes oleajes de río. Y más allá, las 
grutas. Naturalmente, no las veo. Lo «imagino». Sé que serán estalactitas y estalagmitas. Total, una cueva con adornos de piedra. Columnas delgadas y un cicerone, por eso, recuerdo a Ernesto Ortega. Decía, «no vamos al Prado, ¿para qué? Hay cuadros y más cuadros. De Goya, de Rubens, de Velásquez, de otros muchos. Allí pintaron reyes y generales famosos, mujeres, paisajes, etc... etc... Oh yo ya sé que hay cuadros, y buenos. Colores. En fin, yo lo conozco sin verlo». Así decía. En realidad, una teoría como otra cualquiera. Y yo he reencarnado Ortega, «imaginándome», las célebres grutas de Bétharram.

Luego, me regalan rosas. Rojas, rosas, amarillas, grosella. Oh los colores de las rosas. Definición de la delicadeza. Algo que escapa a la retina de tanto querer aprehenderlas. Rosas.

\section{0 mayo, en la habitación. Lluvia}

Me gusta mucho Jean Giono. Le encuentro sabor con Gabriel Miró. $\mathrm{Y}$ a veces con Lorca. Giono aspira el aroma de la naturaleza. Conoce el campo, y la noche, y la vida campesina, y las estrellas. Y sabe sentir los hombres, y la hierba, y el ganado, y el sol, y el bosque y todas las fuerzas del mundo. "Le chant du monde». «Un de Baumugnes». «Regain». Ahora leo, "Que ma joie demeure». Y encuentro esta maravillosa frase: "Chaque fois que cet homme parlait, on avait besoin de silence après». Es como el buen tiempo. Cuando la primavera golpea con su alegría, la sangre bulle en contemplación. Después, necesita mostrar su ardor. Para eso ha hervido, como para eso el hombre aquel había hablado.

Tiene aciertos de gran audacia, Giono. Busca la poesía, porque es poeta. Y la encuentra en los rótulos sencillos de la vida. Que lo diga «les étoiles avaient éclaté comme de l'herbe». Es como yo, prisionero de la hondura poemática de la vida. La ingenuidad, por serlo, es hondísima. Hierba con cosechas sucesivas. Y donde yo intento siempre ver las facetas nuevas de cada cosecha. Que es siempre nueva, por ser desnuda repetición. 


\section{2 y 3 junio, domingo y lunes}

No puede esta cartilla dejar en laguna la proeza. Entre ayer y hoy, he aprendido a montar en bicicleta.

Era curiosa mi ignorancia consciente. Pero allá, en Madrid, se usa más el metro. $\mathrm{O}$ el autobús. O el tranvía.

Hoy siento el aire abofetearme. Bajando las cuestas. Me hace reír saber que ya no me caigo de una bici.

Estaba en casa. Mañana clara. Una bici en la habitación. De pronto, se me ocurre. Idea cortante, como cuchillo. Cogí la «burra». Dos paseos por el patio. Sin caerme. Hecho. Bajo dos kilómetros. Subo una pequeña cuestita. Ya está. Aprendido.

Luego, me decido más. Y camino de Lourdes y de Nay. Con los autos. Nada. No me inmuto. Dentro de unos días, haré en bici el viaje a Pau. Unos $60 \mathrm{kms}$ en bici. Y 12 a pie, ida y vuelta a Montant. Será el grito de mis piernas, luego.

Como un niño, estoy contento. Y gozo. Y río, de mi aprendizaje. Cuando vaya a casa, enseñaré a mis hermanos José Luís y Tere. Es una cosa agradable ser besados por el aire. O abofeteados por la lluvia y el viento.

\section{1 junio, 6 de la tarde. Lluvia}

Acaban de entregarme una carta de ella. Sí, de ella. Una carta que ansiaba con toda la potencia de mis ansias.

Se ata aún más nuestra comprensión. Me quiere. Nos queremos. Y siento este gusto amargo de la lejanía. De una imposibilidad ridícula de llegar allí. Donde me espera ella.

En la encrucijada de la felicidad, el mundo no divisa el amor. Solo el egoísmo. Y yo busco, atormentadamente, mi cariño por ella. En ella. Encontrándonos.

Sé que «esto» "como ella dice- pasará. Es como la lluvia de hoy. Delgada. Pobre. Pronto morirá. Sin fuerzas. Igual ocurrirá con la des- 
gracia que parece aposentarse contra mis ilusiones. Y, como las viñas viejas, caerá en sus raíces. Y días felices nos abrirán la puerta. Queriéndonos ella y yo con el amor íntimo y sereno.

Pero me acuchilla la duda. Un temor de niño mimado. Que quisiera tenerla para mí. Solo. Para mí. Y nada de océanos y kilómetros por medio. Porque, ¿porqué no poder estar junto con ella y gozar nuestro anhelo? Es humano. Pero me responde la amargura. La espera.

\section{2 junio, sábado}

Al lado del horno metálico. Unos mosquitos insolentes me dan la «lata». Abejas que zumban con gruesa indolencia. Las nubes se alargan en el azul barroso. Yo, con pereza.

Las chimeneas del horno «echan humo». Estoy solo, en pleno bosque. Árboles aquí y allá. Ruido de agua. Un espantoso hueco silencioso. Donde gritan pájaros y riachuelo.

Una chimenea está apagada. La he quitado yo. El horno, en hierro, es un gran sombrero negro. Cubre la madera y la tierra. Horno, carbón... sí, hago de carbonero.

¿Por qué no había de anotarlo aquí?

¿Por qué ese título no cuadra con el de poeta, por ejemplo? Es una intolerable indecencia conmigo $-\mathrm{y}$ con otros- hecha.

Oh, que soy bobo. Acabo de leer «l'araignée», de Henri Troyat. Premio Goncourt 1938. Y dice una y otra vez: «la vie ne s'obtient pas, elle s'accepte».

No sé si es verdad. Creo que no. Acaso sí. Me desespero y me aburro. $¿$ Debe permitirse ser invadido por el algodón penetrante de la desesperanza? No. No. Nunca.

Un avión gira su cola gris sobre encinas y castaños.

Sigue saliendo humo del horno carbonero.

Aproximadamente, deben ser las 5 de la tarde. Más o menos. Aquí, no tiene valor una hora sin uso. $\mathrm{O}$ usada. 
A estas horas, me entra ya el mismo frío de ayer.

El 16 actual, París pasó de dueño. Como un traje. Y ya hoy, los alemanes están en Burdeos. Unos días, y los límites estarán en España.

Sé que mi familia tiene plena angustia.

Y yo, aquí, angustiado, leo y hago carbón. Es la más necia estupidez. Gran crimen contra mí.

Pero estoy sereno. Creo que malos ratos vendrán. Puede que los últimos. ¿Dónde ir? ¿Pasear por Madrid? Sueño ya desde hace varias noches. Y veo mi casa. Y mis libros. Y la chavala. Y mis paseos. Pero, no, hay otra cosa.

Una habitación numerada. ¿La merezco? Quiero pensar que no será todo negro. Al fondo, veo como algo limpio. Sí, puede que me permitan estar libre y feliz. Como esta hoja que canta su verde en el árbol.

\section{1 julio}

Me siento determinado por mi mismo. A pesar de la gran influencia de las circunstancias — son ellas las que mandan imperativamente- me siento dominado por mi mismo. Con dirección ventajosa para mis resultados.

He dejado el bosque. Con fecha 27 julio 40, un certificado justifica que dejé el trabajo de carbonero. Y es hoy, con las manos recién lavadas, cuando me dedico de nuevo a «tareas estilo Mont-Oisse». Sí, aquello, que solo persistía en la memoria, vive de nuevo en mis músculos y en mi actualidad. Para ganar mi alimento - la tragedia normal de tener estómago con huecos- trabajo aquí, en esta granja conocida, como campesino. Toda la jornada atando gavillas. Reincorporando a estas notas la particularización agrícola. Hierba, avena, gavillas.

El sol me tuesta. Y una profunda seguridad de vencer me quema. Sí, pronto podré indicar mi nueva residencia. Algo vivo, riente, de gozo con mis pensamientos. Por eso digo, a pesar de malas ocasiones, que me veo y me siento determinado por causas de mí mismo. 


\section{0 agosto}

Ya dejé el bosque. Y el carbón. Y los hornos, que quedan con pereza deseada. Desde que lo dije, nuevas tareas señalan la duda. ¿Acaso seré forzado a «revenir au bois»? así lo dicen rumores y bulos que inquietan el alma.

Ayer y hoy, de "chauffeur» de la segadora. Me paseo mientras la hoja corta el heno. Sube el aroma de hierba bajo las nubes diluidas, a lo lejos, tranquilo está el valle. Abiertamente, se me muestra en la palma convexa de las colinas y de los árboles.

Desde aquí, con mis ojos dictadores, los verdes tienen su melodía natural, ingenua, salvaje. Sin ingredientes de botica, el paisaje es sincero. Habla con sus valles roturados, con sus surcos heridos, con sus vacas paciendo en la tarde clara.

Sueño y me atormento. Esta naturaleza tan viva en su cántico de silencios. Y una sociedad enferma en cortezas muertas y estúpidas. Fracaso del deseo. Mientras, se hunden hojas de calendario. Y yo añoro aún más la etapa libre, sin amistades necias.

\section{3 septiembre 1940}

Inauguración de una nueva etapa en mi vida. Las inauguraciones suelen tener un aire engolado, tieso. Para mí, hoy, todo lo contrario. Simpleza y línea cercada. Es la vuelta a Coarraze. Pueblecito pequeño. Pero agradable. Hemos alquilado una casita. Carretera general Pau-Lourdes.

Nuestra casa, bautizada ya, se llama «la bohemia». Donde conviviremos en gozos y penas. Enrique Zudaire, el andaluz, el valenciano, el cuñado de Enrique y yo.

Bosque de nuevo. Haciendo $\mathrm{m}^{3}$ de leña. Y yo, intendente y cocinero, después de un periodo en que trabajo de leñador como los demás.

Y después - hoy es ya primeros días de noviembre- la gran noticia. Todo me mela en alegría. Soy profesor. PROFESOR. Sí, de nuevo. Con- 
tinuar la línea de Madrid. Doy lecciones de español. Gramática y literatura. Alumnos franceses que hacen su bachillerato.

Esto verdea una ilusión. Salta el gozo, con una acicalada dirección de esperanza.

Nuevas amistades. Nuevos hogares abiertos. Los Barry, los Casuas, los Forgnes. Coarraze y Nay. Me tratan con estima y distinción. Y, sobre la tela optimista de estos días mejorados, el gran hilo amistoso que ata Zudaire y yo.

He sufrido algunos desengaños terribles entre 1939 y 1940 que mellan con dolor. Pero he ganado corazones que inclinan bondadosamente su nobleza.

«La bohemia» es una cinta de luz muy tensa. Mi familia, Agueda y Carmen y Angèle, lecciones de español, la amistad y la esperanza en 1941, que ya viene.

\section{Nota sobre el autor}

Jean-Louis GuereÑa es catedrático emérito de Civilización de la España contemporánea en la Universidad de Tours en donde cofundó el CIREMIA (Centro Interuniversitario de Investigación sobre Educación y Cultura en el Mundo Ibérico e Iberoamericano), que organizó varios coloquios internacionales. Se ha dedicado a la historia social y cultural de España en los siglos xIx y xx. Dentro de ese marco, ha publicado, en francés y en español, muchos trabajos en torno a la historia de la educación, de la sociabilidad, de la sexualidad y del erotismo. 